\title{
THE FOOD, DRUG, AND COSMETIC ACT OF I938: ITS LEGISLATIVE HISTORY AND ITS SUBSTANTIVE PROVISIONS
}

\author{
David F. Cavgrs*
}

The struggle for the enactment of the Food, Drug, and Cosmetic Act of $193^{12}$ may aptly be termed a campaign of attrition. Five years and one day elapsed between the date in 1933 on which Senator Royal S. Copeland of New York introduced what soon was to be christened the "Tugwell Bill"2 and the date in 1938 on which the final legislative step was taken for the enactment of its lineal descendant. ${ }^{3}$ Throughout those five years, there was seldom reason to doubt that some new law would be passed. What the handful of proponents of the measure, in Congress and out, fought for so persistently was to prevent the passage of a law stripped of those provisions which they regarded as essential to consumer protection.

Defeat and disappointment were often their lot, but when one examines the enacted law in the light of the circumstances which attended their effort, it is the degree of success achieved by this group rather than the number of their failures which is the more impressive. As one who for a time shared in their labors, I am, of course, a biased judge, but in this article I have sought to set forth the facts and beliefs upon which I base that judgment. In the sections which follow, I shall attempt first to survey the chief factors, political and economic, which determined the nature of the legislative campaign, then to sketch in broad outline its major moves and the few pitched battles which were fought, ${ }^{3 \star}$ and finally to present briefly the substantive

* B.S. in Econ., I923, University of Pennsylvania; LL.B., 1926, Harvard University. Member of the New York Bar. Professor, Duke University, School of Law. Editor, Law and Contemporary Prodlems. Adviser to the Department of Agriculture with regard to food and drug legislation, 1933-1934. Contributor to legal periodicals.

${ }^{2}$ Act of June 25, 1938, c. 675, 52 STAт. 1040, 21 U. S. C. A. c. 9 (Supp. 1938). (The text of the Act appears in the 1938 Supplement to the United States Code Annotated, but, in citations to Code sections, reference to this supplement will hereinafter be omitted.)

${ }^{2}$ S. 1944, 73d Cong., Ist Sess., introduced on June 12, 1933.

s'The House agreed to the report of the Conference Committee on June 13, 1938. 83 Cono. Rec. 9ror. The Senate having previously agreed to the report, id. at 8738 , the bill was sent to the President who signed it on June 25,1938 .

An invaluable reference work for the student of the Act's legislative history is Dunn, FEDERAL Food, DRUG, AND Cosmetic ACT ( 1938 ), a compilation of the materials comprising the legislative record, excepting the liearings from which only a few extracts are given. For a narrative of the bill's progress up to the fall of 1935, see LAMB, AMerican Chamber of Horrors (1936) c. 11. Miss Lamb, who is on the staff of the F \& DA, devoted the greater portion of her book to an illuminating discussion of the problems encountered by the F\& DA in the enforcement of the old Act. 
provisions of the new law, indicating wherein they differ from those contained in the old law and in the original bill introduced in I933 and its successors. ${ }^{4}$ Since merely to state the textual differences in the provisions discussed in this last section of the article would not suffice to reveal to the uninitiated the significance of the changes made, I have been compelled to attempt some interpretation and appraisal of the provisions considered.

Perhaps the most striking characteristic of the history of the Food, Drug, and Cosmetic Act is the fact that this measure, which was of consequence to the health and pocketbook of every citizen of the country and which importantly affected industries whose annual product totals roughly ten billion dollars, never became the object of widespread public attention, much less of informed public interest. The affected industries were kept posted by their associations and their journals; some national women's organizations sought to apprise their membership of major developments; but the public at large, including persons ordinarily well-informed on national affairs, knew little or nothing of what was transpiring in Congress. I suspect that today only a small fraction of the public knows that a new law has been enacted. ${ }^{5}$

For the existence of this situation, the nation's press must stand primarily accountable. In the long history of the bill, the New York Times seems to have seen fit to give it front-page mention on but a single occasion and then only to report a disturbance in the Senate galleries. ${ }^{6}$ The Times' policy was not exceptional. ${ }^{7}$ Magazines of large circulation were silent or unfriendly, an attitude contrasting sharply with their militant advocacy of the Act of 1906.8 That this policy was due in no small degree to the fact that the measure was widely represented as menacing to advertising revenues seems inescapable. However, some share of responsibility must be attributed to President Roosevelt's disinclination to give the measure a prominent place on his program. Had the bill been accorded, at any stage in its progress, a major fraction

- For a detailed comparison of the original bill with the old Act and the decisions thereunder, see Fisher, The Proposed Food and Drugs Act: A Legal Critigue (1933) I Law and Contemporary ProbLEMS 74.

"At the time of writing, five months after the passage of the Act, the Food and Drug Administration was recciving letters from consumer organizations in various parts of the country inquiring as to the status of the bill.

'This statement is based on the entries in the New York Times Index under the heading, "Food and Drugs." The day on which a first-page story appeared was April 3, 1935, the day following the opening of the Senate debate in that year. President Roosevelt's special message of March 22, I935, advocating the enactment of adequate legislation appeared on the second page.

$T$ The only newspapers of consequence to give consistent support to the measure were the St. Louis Post-Dispatch, the Christian Science Monitor, and Wm. Allen White's Emporia Gazette.

${ }^{8}$ For a brief description of the important role played by magazines at that time, see Regier, The Struggle for Federal Food and Drugs Legislation (1933) I Law and Contemporary Problems 3, 7-9.

- President Roosevelt approved the initiation of the movement for new legislation, sent one message to Congress on its behalf (see p. 12, infra), and from time to time manifested to Congressional leaders his desire to see a satisfactory law enacted. Why he did not press more vigorously for the measure is an interesting field for speculation. Obviously he regarded other legislation as more important and evidently thought its chances of enactment jeopardized by giving equal standing to a bill against which such bitter hostility had been aroused. Moreover, the bill could not easily be classified as a "recovery" measure nor were the practices against which it was directed peculiarly the product of the pre-depression period. 
of the support granted any one of a dozen New Deal laws, no news boycott could have been maintained against it.

Yet under no circumstances would the legislative task have been an easy one. As is noted elsewhere in this symposium, the consumer interest is "difficult to organize for its own protection." Moreover, opposition to the food and drug bill was potentially more formidable than that which could be mustered against most New Deal legislation. Not only are the affected industries huge in size but they are decentralized. Although there are some corporate giants in each of the three producing industries, typically the industries are composed of units of moderate and small size, so well distributed throughout the country that each Representative has at least some affected interest in his district. Moreover, wholesale and retail distributing outlets are legion and, in the case of the drug trade especially, are, on this issue, closely linked to the manufacturers. ${ }^{11}$ Again, the incidence of a food and drug law falls upon important agricultural as well as manufacturing interests. Finally, the measure was of consequence to all newspaper publishers, large and small, and to most publishers of other types of periodicals. There was no opportunity therefore to secure support from regions of the country which would not feel the effects of regulation, nor to align rural against urban interests, or vice versa.

Within the industries themselves there was some division of. interest, but the benefits to be derived from stricter regulation by those branches of the industries most likely to profit by the enforcement of higher standards were not so consequential as to outweigh their fears of burdens which additional regulation of the sort proposed might impose. A considerably milder measure would doubtless have received support from important segments of the trades.

What withheld the opposition from exerting to the full the power that was theirs was chiefly, in my opinion, the fear that the victory would be a Pyrrhic one. The success of most of the units in the industries rests not so much on merits peculiar to their particular products but on consumer good will assiduously cultivated for those products by years of costly advertising. Good will is a sensitive plant. A legislative victory might leave the consumer convinced that the industries could not afford to permit further regulation. Moreover, no such victory could be a decisive one. Inevitably there would be another campaign, and every such campaign would levy its tolls, both by creating business uncertainty and by alienating a still greater number of consumers. ${ }^{12}$

The tactic of the opposition was therefore clear. Some bill would have to be enacted, and the problem was to restrict the measure narrowly enough to avoid the risk of embarrassing changes in merchandising and industrial practices while at the

\footnotetext{
${ }^{10}$ Nelson, Representation of the Consumer Interest in the Federal Government, infra, at p. 152.

12 The Drug Institute of America was represented by counsel at two hearings on the bill. It was an association of " 40,000 members, approximately 37,000 being retail druggists; the balance being manufacturers and wholesale druggists." Testimony of H. M. Bingham, Hearings before the Senate Committee on Commerce on S. 280o, 73d Cong., 2d Sess. (1934) 216 (hereinafter cited as "Hearings on S. 280o").

${ }^{2}$ Cf. Cavers, The Food Industries Need a Good Public Relations Contsel (1933) 5 Food Industries
} $4^{89}$. 
same time establishing in the public mind the belief that an acceptable law had been adopted. Judgment as to the provisions of a law which would meet these specifications varied with the type of product and with the standards of the producer. ${ }^{13}$ Especially was this true of the provisions defining adulteration and misbranding. The maker of antiseptics had apprehensions which differed from those which disquieted the producer of pain-killers; the Florida orange grower's worries had only a common concern in coal-tar coloring to link them to those of the hair-dye manufacturer. Trade association activities and that form of cooperative effort known as log-rolling brought some degree of coherence to the ranks of the opposition with respect to the substantive provisions of the various bills, but it was far easier to achieve a united front on the procedural, administrative and, to a lesser extent, advertising provisions, the incidence of which was much more general.

In view of the foregoing, it is not surprising that the legislative history of the Food, Drug, and Cosmetic Act is a record chiefly of committee action. The bills seldom emerged on the floor of either house and then only for brief periods. The forum was not the Capitol but the House and Senate Office Buildings.

\section{II}

To Rexford G. Tugwell, then Assistant Secretary of Agriculture, ${ }^{14}$ must be given credit for initiating the movement for revision of the Act of Ig06. That act had been amended in but five particulars ${ }^{15}$ since its adoption, and one of those amendments had served only to restore in part the damage wrought by an unfortunate Supreme Court decision. ${ }^{16}$ Criticism of the Act, emanating both from the Food and Drug Administration (hereinafter termed the " $F \& D A ")$ and from students of the field, had been ignored by successive national administrations. The public was unaware of the limited character of the protection accorded them. It was not until the success in r927 of "Your Money's Worth" by Stuart Chase and Fred Schlink, the creation of

\footnotetext{
2s This fact makes for some unfairness when the opposition is treated as a unit, yet such treatment is inescapable in any brief account of the Act's history. I therefore wish to record my appreciation of the fact that many of the questions at issue were ones on which equally public-spirited citizens might reasonably differ. Yet often the opposition's attitude even on such issues seemed governed chiefly by fear that the provisions in question would be maladministered, a fear ascribable to what can best be described as a severe attack of jitters into which the shock of a number of New Deal measures had plunged the affected trades. In the case of food and drug legislation, this was accentuated by the prevalent tendency to regard Mr. Tugwell as a bogey man.

${ }^{14}$ Mr. Tugwell became Under Secretary of Agriculture in 1934. He resigned in I937.

${ }^{15}$ In 1912 the Sherley Amendment, 37 STAT. 4I6, 21 U. S. C. \$ro, "Drugs," par. 3, was enacted to define as misbranded drugs labeled with a "false and fraudulent" statement regarding their therapeutic effect. In $\mathrm{rgr}_{3}$, a reference to the "Secretary of Commerce and Labor" was amended by the deletion of "and Labor," 37 STar. 736. In the same year, the "Net Weight" Amendment, 37 STAT. 732 (r9I3), 21 U. S. C. $\S 10$, "Foods," par. 3, revised the terms of the original provision requiring disclosure of quantity of packaged foods. This requirement was later expanded by a clause rendering it applicable to wrapped meats, 41 STAT. 27I (1919). In 1930, the McNary-Mapes Amendment authorized the Secretary of Agriculture to establish by regulation one standard of quality and of fill of container for any canned food and to prescribe a form of label statement for sub-standard foods, 46 STAT. Ioxg (1930), 21 U. S. C. \$ro "Foods," par. 5.

${ }^{18}$ The Sherley Amendment was necessitated by U. S. v. Johnson, 211 U. S. 488 (I9II), holding that the original misbranding provision did not cover therapeutic claims.
} 
Consumers Research under the latter shortly thereafter, and especially publication of the best-selling "I00,000,000 Guinea Pigs" by Kallet and Schlink in r933 that an appreciation of the deficiencies of the existing law and the advantages taken of them by elements in the industries became at all general.

Mr. Tugwell was acquainted not only with these works but with their authors. When he came into the Department of Agriculture, he sounded out the Chief of the F \& DA, Walter G. Campbell, as to the adequacy of the existing law, and obtained confirmation of weaknesses alleged by its critics. His next step was to secure Presidential sanction for the revision of the Act. This was granted, and he then undertook to organize a group to draft a measure designed to correct the defects in the existing law.

\section{The Drafting of the Original Bill}

This group was comprised principally of officials of the F \& DA and members of the staff of the Solicitor's Office of the Department of Agriculture, ${ }^{17}$ but to assure the presentation of other points of view and to aid in technical problems in drafting, there were added Milton Handler of the Columbia University Law School faculty, ${ }^{18}$ Frederick P. Lee, formerly legislative counsel to the Senate, ${ }^{10}$ and the writer of this article. $^{20}$

This group began its work late in March, I933, and continued until shortly before the close of the hundred days' special session. ${ }^{21} \mathrm{Mr}$. Tugwell took no part in the actual drafting process; he was apprised of its progress and consulted on major problems of policy, but his role was distinctly that of sponsor rather than author of the measure which later was tagged with his name.

The committee was charged with the task of revising the existing law within the administrative framework created for that law, not to revise that framework, even though it were thought insufficient to provide complete protection for the consumer. The $F \& D A$ has been, by and large, a policing organization, acting after the event to detect violations of the law. The prosecution of violations in the federal courts is vested in the Department of Justice. The establishment of, for example, a

Although F \& DA officials who were specialists in specific fields were consulted from time to time, those who took most active part in the drafting work were W. G. Campbell, Chief, P. B. Dunbar, Ass't Chief, and C. W. Crawford, Chief of Interstate Supervision, together with the following members of the Solicitor's Office of Department of Agriculture who hád been engaged exclusively in,food and drug work, P. M. Cronin, J. B. O'Donnell, and J. F. Moore.

${ }^{13}$ Professor Handler had devoted extensive study to trade regulation problems. Sec the identifying note appended to his name, infra, p. 91.

${ }^{2}$ Mr. Lee was then both a practicing attorney in Washington and also professor of law in Georgetown University School of Law. See the identifying note appended to his name, infra, p. 70.

${ }^{20}$ Although I had devoted some study to problems of administrative law and of governmental regulation of industry, my contact with food and drug legislation dated only from 1932 when I had begun the organization of the symposium on "The Protection of the Consumer of Food and Drugs" published in I933 as the first issue of this quarterly.

IT The advisers outside the Department were not able to serve continuously throughout this period, but one or more shared in the drafting of all portions of the bill. 
system of licensing controls, vested in an administration with broad quasi-judicial and quasi-legislative powers, would, if feasible, greatly augment consumer protection. Yet the legislative experience of the bill as drawn clearly demonstrates that a more ambitious undertaking would not have been politically practicable. Moreover, it is questionable that the administrative and scientific problems inherent in any comprehensive licensing system in this field are as yet susceptible of solution.

Early in the drafting process it became evident that the inclusion of the provisions for which experience in the enforcement in the old Act had demonstrated the need could not possibly be effected merely by amendments to that act. The drafting of a new act was essential. The source of suggestions what that act should contain was primarily the F \& DA and not its advisers, although each made some contributions. ${ }^{22}$

Need was felt in the course of the drafting work to obtain the views of representatives of the affected industries, ${ }^{23}$ but the manner of eliciting their advice presented a difficult problem. Each of these industries is comprised of many branches whose interests and views on questions of legislative policy are far from identical. Consultation with representatives of each of these branches was simply not feasible if a bill were to be introduced before the close of the special session, an objective thought important, though enactment at that session was not expected. Moreover, the drafting group was compelled by reason of the intricacy of its task to proceed slowly. Submission to the industries of proposals in piecemeal form would have prevented their adequate appraisal. In this dilemma, it was decided that the best procedure would be to call meetings of representatives of the affected trades and, instead of submitting partial drafts to them, merely to seek the expression of their opinions whether and how the Act might be properly revised.

In accordance with this plan a conference with drug trade representatives was held on April 27, 1933, and one with food trade representatives the day following. These conferences, while making clear the prevalence of opinion that the Act was in need of revision and proving productive of some suggestions of value, on the whole were unsatisfactory. Considerable disappointment was manifested by those present that no provisions were submitted for consideration. Viewed in retrospect it seems probable that the progress of the legislation would have been facilitated if no attempt had been made to introduce a bill in the special session and, instead, the draft had been made available upon its completion to industrial and consumer groups to obtain their reactions and suggestions. Some of the revisions which were later forced by industry opposition could have been made before the beginning of the regular session in January, 1934. The course followed served to arouse suspicion and hostility which thereafter could never be completely allayed. Opposition there inevitably would have been, but it is doubtful that, if the other procedure had been followed, this opposition 1 would have gained the impetus that it did.

20 The notion was later disseminated widely that the bill was the product of inexperienced pedagogues. On occasion it was intimated that they were in receipt of suggestions from the Comintern.

Questionnaires were sent to state food and drug officials and to interested private organizations and individuals to secure their suggestions. 


\section{Consideration by the 73d Congress, 1933-1934}

The completed draft was first submitted to the chairmen of the Committees on Agriculture in both House and Senate. ${ }^{24}$ When they declared their inability to consider it, the draft was submitted to Senator Copeland of New York, a member, and later chairman, of the Commerce Committee of the Senate, who had previously manifested interest in some matters affecting the F \& DA. Senator Copeland was not only a physician but had once been the Health Commissioner of New York City. $\mathrm{He}$ introduced the measure without change and, as he later confessed, ${ }^{25}$ without having completely read it. The special session however was rapidly drawing to a close. The bill, bearing the number S. $1944,{ }^{28}$ was referred to the Committee on Commerce and a sub-committee consisting of Senator Copeland, chairman, and Senators McNary and Caraway, was appointed to consider it.

S. I944 received a far from cordial welcome from the industries. However, the attention of the food industries for a time was distracted from it by the activities of the NRA and AAA which were rapidly accelerating during the summer and fall of '33. The drug industry, upon which the impact of the measure was much more severe, was promptly informed of its iniquity. A swelling tide of protest rose in the periodicals and meetings of the trade. The public, however, had little opportunity to learn of the existence of the measure. The most militant consumer organization, Consumers Research, damned it with faint praise and many criticisms. The principal source of consumer information was the F \& DA's "Chamber of Horrors."

The F \& DA was forbidden by a law ${ }^{27}$ applying to governmental agencies generally to spend public funds to influence members of Congress with respect to pending legislation, but the Administration did succeed in making vivid the need for a new law by the device of assembling exhibits illustrative of the operation of the existing Act, a step within its legal powers. The "Chamber of Horrors," to use the name conferred by a columnist who visited it, was an array of pictures, labels, and advertisements of ineffective or harmful and occasionally lethal nostrums, dangerous cosmetic preparations, and adulterated or deceptively packaged and labeled foodstuffs which the F \& DA, under its existing powers, either could not reach or was greatly handicapped in reaching. The exhibit gradually achieved a considerable measure of public notice, thanks in no small degree to the diatribes which it evoked from the industries whose skeletons were thus uncloseted.

By December 7 and 8, I933, when hearings on S. I944 were scheduled, trade opposition had been well mobilized. Some consumer support had been hurriedly marshalled, chiefly among women's organizations, but the great majority of those testifying at the hearings were representatives of industry. Very frequently attacks on the bill were prefaced by admissions that the existing law was in need of amend-

\footnotetext{
${ }^{24}$ Senator Ellison D. Smith of South Carolina and Representative Marvin Jones of Texas.

ss See 79 Cong. Rec. 5024 (I935).

${ }^{20}$ To follow the narrative, it will be essential for the reader to keep in mind the numbers of the five principal bills, S. 1944 (1933), S. 2000 and S. 2800 (1934), S. 5 (1935), and S. 5 (1937).

27 Third Deficiency Appropriation Act for 19I9, 4I STAT. 35.
} 
ment. The burden of the complaint was that a few amendments alone would have sufficed, and that so general a revision as had been undertaken was not only unnecessary but would destroy the benefit of the accumulated decisions interpreting the old law and thus compel the courts to start afresh. Few sections escaped criticism. It was notable however that the criticisms frequently were directed to the phrasing of sections rather than to their substance. An outstanding example of this was the language of the sections defining false and misleading labeling and advertisements: "An advertisement [or labeling] . . . shall be deemed to be false if in any particular it is untrue, or by ambiguity or inference creates a misleading impression. ..."28 The fact that this provision represents a close paraphrase of language used by the Supreme Court ${ }^{29}$ in one of those decisions which the opponents of S. I944 were so anxious to preserve seemed in no way to assuage the pain which this provision caused.

Branded as especially sinister were the rule-making powers granted to the Secretary of Agriculture with respect to certain problems on which a broad prohibition, not supplemented by regulations, would either have been ineffective or, by uncertain or unequal application, have worked injustice. Although the opposition persistently stressed the dangers of uncertainty, these seemed inconsequential before the peril that the Secretary would become "Czar" of the industries.

One complaint specific to the drug industry was the charge that the bill represented a calculated attempt to deprive the American people of their right to "selfmedication," a charge thereafter to be constantly reiterated with illustrations which were notable examples of hyperbole. ${ }^{30}$ The principal concern of the food industry was aroused by a provision authorizing the Secretary to promulgate grades of quality for food products. However, the chief spokesman in opposition to this proposal came from the ranks not of the food industry but of the publishers who saw in the establishment of such quality grades a menace to the benefits derived by the American housewife from the advertising of branded goods. ${ }^{31}$

Spokesmen for the consumer and public health agencies were generally favorable to the bill. However, no appearance was made on behalf of the American Medical Association, its representative merely filing a brief complaining of the rule-making powers conferred on the Secretary. The representative of Consumers Research prefaced an attack on the bill for its inadequacy by insisting that Senator Copeland was disqualified to sit as chairman and should be removed.

This charge, repeated at a subsequent hearing and given considerable publicity,

$\approx$ S. $1944, \$ 9$ (a). The same language was used in the definition of misbranding. Id. $\$ 6(\mathrm{a})$.

20 "Deception may result from the use of statements not technically false, or which may be literally true. The aim of the statute is to prevent that resulting from indirection and ambiguity, as well as from statements which are false." U. S. v. 95 Barrels of Vinegar, 265 U. S. 438, 443 (I924).

${ }^{2}$ An all-too-typical example follows: "It would be a real hardship if you or I could not take an aspirin tablet or mineral oil or bicarbonate of soda without a physician's prescription. No, the bill does not say that, but such things are possible under its provisions." Calkins, Another Look at the Pure Food Bill (Dec. 1933) 97 Good HousekeEPING 90.

${ }^{3}$ See testimony of C. C. Parlin on behalf of the National Periodical Publishers, Hearings before. $a$ Subcommittee of the Senate Committee on Commerce on S. 1944, 73d Cong., 2d Sess. (1933) 318. (Hereinafter cited as "Hearings on S. r944.") 
requires consideration here. It was based on the fact that Senator Copeland was giving brief health talks on radio programs advertising Fleishman's Yeast, a product which Mr. Kallet declared would be adversely affected by the advertising provisions of the pending bill. ${ }^{32}$ On the question of principle raised by this conflict of interest opinion will differ, but that Senator Copeland sought to sabotage the measure which he sponsored neither I nor those with whom I was associated in work on the bill believe. Had he desired to "sell out" the public, this end could easily have been achieved. Instead, he worked assiduously to obtain as good a law as he believed he could possibly secure. There is no doubt but that this effort shortened his life. $\mathrm{He}$ died of a condition rendered acute by overwork just four days after the enactment of the law.

Perhaps a more successful protagonist for the measure could have been found. Throughout his legislative career, Senator Copeland had sought chiefly to conciliate rather than to override opposition, a technique which, of course, compels compromise. Moreover, he did not enjoy the political favor of President Roosevelt. But it is by no means certain to me that these factors were wholly detrimental. Unless the Administration had been willing to give the measure a place on its early "must" lists; an intransigent attitude might have led to the final defeat of the bill or the enactment of one of the many inadequate substitutes which were introduced. Senator Copeland's known conservatism served to offset in some degree the antipathy displayed in Congress to Mr. Tugwell, an antipathy cultivated by the opposition as one of its principal assets.

At the conclusion of the hearings on S. 1944 it was obvious to those who had shared in its drafting that some revision would be necessary. Certain amendments were called for because of deficiencies in the bill which had become evident either before or at the hearings. Other amendments seemed desirable because thereby criticisms could be met without requiring substantial sacrifices in objectives. Still others, though regretted, seemed inescapable if the opposition to the bill were to be reduced to a point where it could be overcome. Already it was clear that competing bills drafted by industry counsel would be introduced and there was a real risk that one of these, which were far from satisfactory, ${ }^{33}$ would be enacted unless the opposition to S. I944 could be divided. Accordingly the group which had drafted the original measure (with the exception of Mr. Handler and Mr. Lee who had been appointed to other governmental posts) undertook to revise S. x944. The revision thus effected

${ }^{*}$ See testimony of A. Kallet, representing Consumers Research, id. 355. Senator Copeland did not comment on the sponsor's product. He spoke subsequently on the programs of other nationally advertised products. See testimony of J. B. Matthews, representing Consumers Research, Hearing bcfore a Subcommittee of the House Committee on Interstate and Foreign Commerce on $H . R .6906, H . R .8805, H . R$. 8941, and S. 5, 74th Cong., Ist Sess. (1935) 507. (Hereinafter cited as "House Hearings on S. 5.")

${ }^{8}$ Quite the worst of these was H. R. 6376, introduced by Representative Black of New York and known as the Black Bill. It was drawn by a committee of the National Drug Trade Conference and proffered at the hearings on S. I944 by Đr. J. H. Beal, identified as "one of the outstanding leaders in pharmacy," who outdid counsel for industry in his attacks on S. 1944 and later S. 2800. The text of the bill appears at the end of Dr. Beal's testimony. Hearings on S. 1944, at II4. 
was approved by Senator Copeland with some changes and introduced by him as S. 2000 at the second session of the 73 d Congress on January 4, r934.

S. 2000 compelled some change in position on the part of spokesmen for the industries, ${ }^{34}$ but it is doubtful whether the hostility rampant in the rank and file as a consequence of the propaganda against the "Tugwell Bill" was materially lessened. On the other hand the modifications it introduced brought forth sweeping condemnations from consumer spokesmen of the Consumers Research group. Dubious of the efficacy of S. I944, they were ready to place the worst construction upon all relaxations in its provisions. Judgment of the effect of the changes was expresed by the term "emasculated." This notion was circulated most widely among liberal groups whose aid might reasonably have been anticipated. The result was that they promptly developed a defeatist attitude toward the bill, and such support as they might have rendered in preventing the far more damaging changes which were still to come was largely withheld. The representatives of the women's organizations had a more realistic understanding of the possibilities for legislation in this field and, while disappointed by a number of the changes which were made, increased rather than diminished their efforts to secure the best possible bill. ${ }^{35}$

In the months that followed Senator Copeland was subjected to constant pressure from a great variety of special interests, each of which enjoyed influential Congressional support. Still hoping to conciliate this opposition or at least to prevent a shift in Congress to the support of the competing McCarran-Jenckes Bill, ${ }^{\mathbf{3 6}}$ Senator Copeland consented to a number of the amendments proffered. Ultimately changes in S. 2000 became so numerous that he decided to introduce a revision of the bill under a new number. The supplanting bill, S. 2800 , differed from its predecessor in one very material respect: authorization to establish more than one quality grade for any food was withdrawn, a concession which sharply diminished the opposition of publishing interests. $^{37}$

\footnotetext{
s In particular the complaint of dictatorial power in the Secretary was diminished by the provision for a Committee on Public Health and a Committee on Food Standards. These committees were charged with the duty of recommending regulations to the Secretary within their respective fields, and no regulation could be promulgated by him without their approval. S. 2000, \$22. This provision was greeted by a coolness which contrasted sharply with the warmth engendered by the menace of dictatorship, and it disappeared at the end of 1936 , after having served at least to work an estoppel on some critics of the bill. The arguments for and against these committees from the consumer's standpoint seem to me to be evenly balanced.

The work of these organizations was intelligent, persistent, and effective. It is briefly described, and the cooperating bodies listed, in Baldwin and Kirlin, Consumers Appraise the Food, Drug, and Cosmetic Act, infra, at p. I44.

${ }_{33}$ This bill was prepared by Charles Wesley Dunn, counsel for a number of important trade associations in the field. It was distinctly superior to the Black Bill, supra note 33, and hence a more formidable rival.

st This and other changes from S. I 944 led to the adoption by a committee of the National Publishcrs Association, representing 150 leading magazines, of a resolution stating that "those provisions of S. 2000 on which we feel competent to express an opinion are satisfactory." See testimony of C. C. Parlin, Hearings on $S .2800$, at 30 . The National Editorial Association, a large organization of small town newspapers, took a similar position with respect to S. 5 in $x 935$. See testimony of Erwin Funk, Hearings before a subcommittee of the Senate Commitee on Commerce on S. 5, 74th Cong., Ist Sess. (1935) 310. (Hereinafter cited as "Senate, Hearings on S. 5.")
} 
Hearings on S. 2800 were held before the full Committee on Commerce from February 27 to March 3, I934. The opposition continued the attack begun at the hearings on S. I944 although the attacks were rather more temperate. Consumer representatives were present, greatly outnumbered by industry spokesmen. Mr. Kallet of Consumers Research repeated his attack on. Senator Copeland, a tactic which largely impaired the reception given his subsequent analysis of the deficiencies of the bill. ${ }^{38}$ Dr. Woodward from the A. M. A. in his appearance denied a prevalent charge that the A. M. A. had written the bill or was a moving force behind it and then corroborated that statement by the tepidity of his support of the measure. ${ }^{30}$

At these hearings there first became evident a source of opposition which was later to produce the greatest defeat for the advocates of the bill. Commissioner Ewin L. Davis of the Federal Trade Commission appeared at the suggestion of the committee to discuss the bill from the standpoint of the jurisdiction of the Commission over false advertising. Although denying that he was opposing the bill, ${ }^{40}$ Commissioner Davis submitted amendments which would have required false advertising cases to be brought before the Federal Trade Commission (hereinafter called the "FTC") instead of the courts. ${ }^{41}$

Little progress on the bill was made during the remainder of the session. A number of amendments were made in committee, some weakening, some strengthening. On May I 6 the bill came on the floor of the Senate from which it disappeared after an hour's discussion. ${ }^{42}$

\section{Consideration by the 74th Congress, 1935-1936}

With the beginning of the first session of the 74th Congress came a new bill, S. 5, introduced by Senator Copeland on January 4, I935. S. 5 did not differ very consequentially from the state which $S .2800$ had reached by the end of the previous session but it was altered materially in form, the definitive provisions being grouped by commodities rather than by types of offenses. With the introduction of the bill there began once more the familiar story of demands for amendments, some of which were yielded to. Senator McCarran reintroduced his bill and soon after Representative Mead of New York introduced a bill prepared by Mr. James F. Hoge, counsel for the Proprietary Association which comprises the leading proprietary drug manufacturers. A sub-committee of the Commerce Committee with Senator Bennett C. Clark of Missouri as chairman, held hearings on S. 5 for three days early in March.

On March 22d President Roosevelt sent a special message ${ }^{43}$ to the Congress in which, after pointing to the need for maintaining high standards of integrity in food, drugs, and cosmetics and to the fact that "loopholes have appeared in the old law which have made abuses easy," he said:

"It is time to make practical improvements. A measure is needed which will extend the controls formerly applicable only to labels to advertising also; which will extend protection

${ }^{3}$ Hearings on S. 2800 , at 277 .

IId. at 349-370.

${ }^{10}$ Id. at 233 .

"Id. at 239.

78 Cong. Rec. $8955-8967$ (1934).

- For the text of this message, see 79 Cong. Rec. 4262 (1935). 
to the trade in cosmetics; which will provide for a cooperative method of setting standards and for a system of inspection and enforcement to reassure consumers grown hesitant and doubtful; and which will provide for a necessary flexibility in administration as products and conditions change. . . . It is my hope that such legislation may be enacted at this session of the Congress."

Earlier the same day the Committee on Commerce had reported out S. 5,44 still more changes having been made. It reached the floor of the Senate on April I, I935, and there began the most extended debate on the measure which took place in either house during its five years of consideration.

By this time the major issues which were to dominate the controversy over the bill in the succeeding three years had become apparent, and before resuming the narrative I shall describe them briefly. The first of these issues related to the power to make "multiple seizures." Under the old Act the F \& DA had power to institute a criminal prosecution against an offender and to seize an offending article pursuant to court process. The article seized was condemned unless an interested party intervened as claimant and the government failed to prove the article to be adulterated or misbranded in violation of the Act. ${ }^{45}$ Where the F \& DA had cause to believe that a food or drug constituted either a danger to health or a gross fraud on the consumer it was its practice to seize the product widely to discourage dealings in it. ${ }^{46}$ This procedure was at once an effective method of consumer protection and a heavy burden to the producer who, if he believed his goods to comply with the law, was compelled to intervene in actions pending in a large number of jurisdictions. Moreover, these jurisdictions would often be remote from his place of business.

The drive to restrict the power to make multiple seizures was led by the Proprietary Association. Especially prominent in this effort of the Association were representatives of the Vick Chemical Company of North Carolina, but that company's objective was shared by many other large concerns, among them the Lambert Pharmacal Company of Missouri, the maker of "Listerine." It was perhaps not surprising, therefore, that Senators Josiah W. Bailey of North Carolina and Clark of Missouri, both members of the Committee on Commerce and able debaters, should enter the lists on behalf of their industrial constituents to engage in the familiar and congenial task of combatting Bureaucracy.

The second major issue was whether control of advertising of foods, drugs and cosmetics should be given to the F \& DA or whether the power of the FTC, which already had jurisdiction of interstate advertising of all commodities, should remain exclusive. Since, during the twenty-odd years which the FTC had enjoyed this jurisdiction, there had developed the condition which had led to the demand for new controls over advertising, a proposal which looked to the continuation of the status

"The bill was accompanied by SEN. REP. No. 36I, 74th Cong., rst Sess. (1935). A week later minority views were filed by Senator Bailey (N. C.) who was joined by Senators Clark (Mo.), Guffey (Pa.), Bachman (Tenn.), and Donahey (Ohio).

*For a description of the seizure procedure, see Lee, The Enforcement Provisions of the Food, Drug, and Cosmetic Act, infra, pp. 79-83.

"Only where the product was imminently dangerous to health would the F \& DA attempt complete removal from the market, an undertaking normally beyond its resources. 
quo seemed palpably inadequate as a reform measure. ${ }^{47}$ The principal objections voiced to FTC control were directed to the fact that its "cease and desist" procedure had little or no deterrent effect on the advertisers' tendency to hyperbole, since the most rigorous penalty for an offense would be a Commission order not to do it again, an order which if violated could lead to nothing more drastic than a judicial order not to do it again. ${ }^{48}$ Other objections to retention of exclusive jurisdiction by the FTC were based on the fact that it had neither the scientific staff nor facilities comparable to the F \& DA's and the fact that the Commission had often failed to proceed against advertising claims which the $F \& D A$ had driven from the labels of the same products. $^{49}$

Undoubtedly there was at the outset a widespread if not universal preference among the affected industries for the FTC's continuation as supervisor of advertising. But as modifications were introduced into the food and drug bills' advertising provisions more and more of the leading food and drug advertisers-and publishers as well-came to the conclusion that effective control of the black sheep of the industries could be had only through $F \& D A$ action. Possibly, therefore, the issue would not have been forced but for the vigilance of the FTC, which manifested a lively disinclination to see another governmental agency share its jurisdiction. In industry ranks the FTC found potent support among the proprietary drug manufactures; the Proprietary Association and its smaller brethren, the United Medicine Manufacturers of America and the Institute of Medicine Manufacturers, all worked in its behalf. The principal Congressional champions of the FTC were Senator Clark and Chairman Clarence F. Lea of the House Committee on Interstate and Foreign Commerce.

The third major issue related to the judicial review of regulations promulgated by the Secretary of Agriculture. Although the power to make regulations having the force and effect of law was conferred on the Secretary by a number of provisions in the bills, a single one was responsible for making this issue so significant. All the bills contained a provision defining as adulterated any food containing an added poisonous ingredient, subject, however, to power in the Secretary to establish by regulation tolerances for poisons which could not be wholly eliminated in the production or preparation of foods for market. The foods most seriously affected by these provisions were the fresh fruits and vegetables. Efforts to remove insecticide

FIn I933 the FTC directed its Board of Investigation, which had been created in 1929, to serutinize advertising and especially radio scripts. Over 400,000 scripts have been reviewed in a single year. See statement of Commissioner E. L. Davis, House Hearings on S. 5, at 637 . This activity led to an increase in the number of proceedings with respect to food, drugs, and cosmetics. But even after this action had been taken the standard of advertising was far from such as to lead most observers to share Commissioner Davis' satisfaction in the Commission's achievements.

${ }^{4}$ FTC Act $\$ 5,15$ U. S. C. $\$ 45$. If a cease and desist order were violated, the FTC could sue in the Circuit Court of Appeals for an injunction restraining future violations. The FTC's powers wcre increased in 1938 by the Wheeler-Lea Act, discussed, p. $x 8$, infra, and at greater length in Handler, The Control of False Advertising under the Wheeler-Lea Act, infra, p. $9 \mathrm{r}$.

${ }^{6}$ Some apologists for the FTC have attributed the limited efficacy of its activities to the Raladam case, Federal Trade Comm'n v. Raladam Co., 283 U. S. 643 (1931), rendering proof of injury to competition essential in proceedings instituted by it. But Commissioner Davis testified that the "Raladam case is an extreme case, and has been applied, and can be applied, in very few instances." Hearings on S. 2800, 234. 
sprays containing lead and arsenic from fruits and vegetables have never been wholly successful, a small residue of the poison remaining. The $F \& D A$ has devoted for many years a substantial portion of its small annual appropriation to the effort to keep from the market fruits and vegetables containing poisonous spray residues in excess of the tolerances fixed by administrative order. Where its action has been contested, it has been necessary for the F \& DA not merely to prove that the tolerance was exceeded but that the amount of poison contained rendered the product dangerous to health. To establish to the satisfaction of a jury the fact that what seemed to be an infinitesimal amount of poison was actually a danger to health has proved exceedingly difficult, and the power of the F \& DA to police this important field has been correspondingly impaired. By giving the regulations fixing tolerances the force and effect of law, it would become necessary for the government only to prove that the tolerance established thereby had been exceeded. This being done, the only defense left to the claimant would be an attack upon the regulation as unconstitutional. Hence the importance of judicial review.

The burden of protecting American constitutional liberties from this threatened encroachment was assumed chiefly by the International Apple Association, which had almost twice as many senatorial friends as there are apple-growing states. The Association had sustained a severe shock in the spring of 1933 when Assistant Secretary Tugwell had reduced the tolerance for lead arsenate from 0.02 grain per pound to 0.014 grain. Vigorous protest had led Secretary Wallace soon after to increase the tolerance to 0.02 grain, but the experience made a lasting impression on the applegrowers. Their objective thereafter was to broaden the power of the courts in passing upon the regulations so as to enable a court reviewing a regulation to reach its own judgment on the facts rather than to compel it to accept the Secretary's finding of fact if supported by substantial evidence-the criterion of validity established in federal administrative law. If the judgment of the district courts on such questions of scientific fact could thus be substituted for the opinion of the experts consulted by the Department, the apple-growers felt that they could face the future with aplomb. Of course the amendment they advocated would apply equally to court review of regulations issued under other sections of the Act.

To return to the narrative, the debate on S. 5 in the Senate in the spring of 1935 revolved chiefly about the first of the three issues noted above-multiple seizures. Senator Bailey sought by amendment to limit the power of seizure in misbranding cases to one seizure only, except where, on an order to show cause, the Secretary showed that the article was "misbranded in manner and degree as to render such article imminently dangerous to health." This would have left unimpaired the power to make multiple seizures of adulterated goods, but to restrict this power Senator Bailey offered a further amendment transferring to the section defining misbranding the provision declaring a drug to be adulterated if "dangerous to health under the conditions of use prescribed in the labeling or advertising thereof."

The effect of these two amendments was to leave proprietary drugs virtually im- 
mune from multiple seizure. Adulteration in such products is rare since they need comply with no standard save their own. Only a very few such drugs are "imminently dangerous to health" in the sense that their administration will cause physical injury. The real danger that is caused by the ineffective nostrum comes from its use in conditions where the safety of the sufferer is dependent upon the prompt application of appropriate remedies. For example, use of "Banbar," an extract of the horsetail weed, ${ }^{50}$ by a diabetic in lieu of insulin, would lead to death just as surely as if the harmless weed were a deadly poison. Again, if another influenza epidemic brought on the market a flood of antiseptics, counter-irritants, laxatives and painkillers labeled or advertised directly or indirectly as efficacious in the treatment of influenza and pneumonia, ${ }^{51}$ then, under the amendments advocated by Senator Bailey, the F \& DA would be unable to make more than a single seizure of any offending product until, some months later after the crisis had passed, it succeeded in securing a favorable judgment in the action. Senator Copeland was impassioned in his opposition to the amendments, but he stood alone in the debate and was scarcely a match for Senators Bailey and Clark. The amendments were adopted by a vote of 44 to $29 .{ }^{52}$

With these and further amendments, including one fathered by Senator Vandenberg which provided that the single seizure action allowed by the Bailey Amendment should on "motion, be removed for trial to the jurisdiction of the claimant's residence" (thereby assuring a jury drawn from the manufacturer's rather than the consumer's bailiwick) the bill was passed by the Senate on May 28, r935, without a record vote. ${ }^{53}$

This bill was then referred to the House Committee on Interstate and Foreign Commerce and a sub-committee of five representatives under the chairmanship of Representative Virgil Chapman of Kentucky ${ }^{54}$ was appointed to hold hearings. These hearings, held on twelve days in July and August, I935, brought forward the same group of opponents but their reception differed strikingly from that accorded them by the Senate committee. Senator Copeland had on occasion taken issue with persons testifying before his committee, but seldom did he probe into their records or those of the products which they represented. Representative Chapman, however, obtained at an early stage in the hearings information with respect to the products represented by persons appearing before the sub-committee. His examination of witnesses based on this information, although conducted with the utmost suavity, must, if the record affords adequate evidence, have been productive of extreme discomfort

\footnotetext{
co "Banbar" was prominent in the "Chamber of Horrors." Its produces, when tricd under the Sherley Amendment, was acquitted. The case is described in Lamb, American Chamber of Horrors, 64-66.

${ }$ How the trade rose to the occasion afforded by a localized epidemic in 1929 is described in LAMB, American Chamber of Horrors, 134-I40.

${ }^{2} 79$ Cong. Rec. 5230 (1935). Party lines were disregarded in the vote. Senator Copeland voted in the affirmative so that he might move for reconsideration, but the motion was never put and he continued on in the hope of a later compromise.

s The other members were Representatives W. P. Cole (Md.), E. A. Kenney (N. J.), James Wolfenden (Pa.), and R. C. Reece (Tenn.).
} 
to a number of witnesses. The nearly 800 pages of testimony before this sub-committee contains as lively reading matter as may be found in any of the proceedings of Congress or its committees, but seemingly the testimony barely met the standard of "news fit to print."

In I936, action on the bills was confined to the committees until late in the session, the second of the 74th Congress. In May the House Committee reported out a bill which bore striking testimony to the labors of the FTC and its industry supporters. ${ }^{50}$ The House amendments to S. 5 improved in some respects the provisions of that measure as it had passed the Senate, especially as regards multiple seizure, but the House bill gave exclusive jurisdiction to the FTC to deal with false advertising. The bill reached the floor of the House on June 19 , I936, on a motion to suspend the rules, which permitted only twenty minutes debate on each side. At the expiration of the allotted forty minutes, the bill was passed by a vote of 151 to 27.57

Conferees were appointed from both houses and, in the conference which followed, the house conferees prevailed on most points, but a deadlock was reached on the issue of jurisdiction over false advertising. An eleventh-hour compromise was attempted by Senator Copeland who moved that the Senate recede from its disagreement to the House amendment and agree to it with an amendment which he had hurriedly drafted giving jurisdiction to the $F \& D A$ only over advertising affecting health. ${ }^{68}$ The motion promptly carried and the bill, thus amended, was sent to the House.

The debate in the House ${ }^{58}$ took place late in the evening of June 20 . It was a short one. The issue was nicely defined by Representative McReynolds of Tennessee who said: "Now, Members of the House, what are you going to do about it? Are you going to turn this over to Tugwell for enforcement or are you going to leave it with the Federal Trade Commission with such men as Judge Davis and other men from this House on that Commission? [Applause.]"60 Representative Rayburn, majority floor leader, tried desperately to stem the tide, and in the course of his remarks observed: "There might be a little lobbying around here by some people, but there is nobody who has lobbied around this Capitol on any bill in the 23 years I have been in Congress more than the members of the Federal Trade Commission have lobbied on this bill, and I love the Federal Trade Commission." 61 When the vote was taken, the score stood: Tugwell, 70; Judge Davis and the other House alumni, I90. ${ }^{62}$ Thus ended the career of the food and drug bill in the 74th Congress.

80 The New York Times carried news stories relating to the hearings after six of the twelve days, July $23,25,26,30$, and Aug. 9, II, 1938. The six stories, all on inside pages, totalled a length, including heads, of approximately three columns.

${ }^{50}$ H. R. REp. No. 2755, 74th Cong., 2d Sess. (May 22, I936). Three members of the House committee, Representatives Chapman (Ky.), Mapes (Mich.), and Merritt (Conn.), filed "additional views" stating arguments against retention of exclusive jurisdiction over advertising in the FTC.

${ }^{67}$ For the debate and action of the House, see 80 Cong. REc. 10230-10244 (1936).

${ }^{88}$ See $i d$. 10514-10520. The text of the bill is included.

${ }^{80}$ See id. 10675-10680. ${ }^{\circ 0} \mathrm{Id}$. 10678.

${ }^{a 1}$ Id. 10679 .

${ }^{\circ 2} \mathrm{Id}$. 10680 . 


\section{Consideration and Enactment by the 75th Congress, $1937-1938$}

When the 75th Congress began its first session in January, 1937, Senator Copeland succeeded in getting "S. 5" again for the designation of his bill. No hearings were held on this measure but few sections escaped amendment at the hands of the Senate Commerce Committee. ${ }^{63}$. The provision with respect to multiple seizures was altered in the amended bill so as to be somewhat preferable from the standpoint of consumer protection than the original provisions of the Bailey Amendment. The bill was brought to the floor of the Senate on March 8, $1937,{ }^{64}$ and the next day was passed. ${ }^{05}$ The session closed, however, without action by the House, nor did the House act during the brief special session in the fall of $1937 .^{66}$

However, the advocates of FTC control over food and drug advertising had begun a flank attack before the close of the first session of the 75th Congress which led to action early in the third session. In the first session the Senate had passed a billor introduced by Senator Wheeler of Montana which was designed to strengthen the sanctions of the FTC Act ${ }^{68}$ and to enlarge the FTC's powers by freeing it from the restrictions imposed by the United States Supreme Court in Federal Trade Commission v. Raladam Company, ${ }^{69}$ holding that the Commission could not issue a cease and desist order against false advertising unless injury to competition were shown. This bill was in the hands of the House Committee on Interstate and Foreign Commerce to which S. 5 had been referred. The chairman of that committee, Reprecontrol of food and drug advertising by writing into the bill to amend the FTC Act sentative Lea of California, devised the plan of forcing the issue with respect to special powers with respect to food, drug and cosmetic advertising.

The new provisions, as reported over the objection of three members of the committee, ${ }^{70}$ defined "false advertisement," "food," "drug," "device," and "cosmetic"; 71 declared the dissemination of false advertising to constitute an "unfair or deceptive

* See SeN. Rep. Nos. 91, 152, 75th Cong. Ist Sess. (1937).

a 8 I CoNG. REc. 196I (1937).

* Consideration was directed chiefy to the Committee's amendments; there was no general debate. Id. 2001-2021. After passage, Senator Copeland offered for the record a vigorous criticism of the bill prepared by fourteen national women's organizations.

Bills were introduced at this session to create special controls for new drugs. See p. 20, infra.

or S. r077, 75th Cong,, Ist Sess. (1937), passed March 29, 1937. 81 Conc. REc. 2087 (1937). An identical bill had been passed by the Senate in the previous session.

- The principal provision to this end was an amendment limiting the power of a person subject to 2 cease-and-desist order to seek judicial review thereof to a period of 60 days and imposing a civil penalty of $\$ 500$ for violation of the order after it had become final, plus a penalty of $\$ 25$ per day for each day the violation continued.

${ }^{\infty} 283$ U. S. 643 (I93I).

${ }^{70}$ H. R. REP. No. I613, 75th Cong., Ist Sess. (1937), contains the Committee's report, the text of the bill, and the "additional views" of Representatives Chapman, Kenney, and Mapes, who argued that the methods of enforcement available to the FTC under the bill were inadequate to deter false advertising of food, drugs, and cosmetics.

71 The definitions of "food," "drug," "device," and "cosmetic" were the same as those contained in the food, drug, and cosmetic bill then before the House Committee. The definition of "false advertising" paralleled that of "misbranding" in the latter bill. For the text of the House bill at this stage, see 83 CoNG. REC. 12462-12467 (I937). 
act or practice" under the FTC Act; authorized the Commission to secure a temporary restraining order from any district court to enjoin the dissemination of an advertisement believed to be false, pending the institution and determination of a cease and desist proceeding before the Commission; and finally declared any person violating the Act by disseminating a false advertisement to be guilty of a misdemeanor "if the use of the commodity advertised may be injurious to health because of results of such use or if such violation is with intent to defraud or mislead."

The bill reached the floor on January 12 , $1938 .{ }^{72}$ Those members of the House Committee who had unsuccessfully opposed the denial of jurisdiction of advertising to the $\mathrm{F} \& \mathrm{DA}^{73}$ resolutely sought to secure the amendment of this bill so as to provide that persons violating the above provisions of the Act should be subject to a civil penalty of not more than $\$ 3000$ or, if the commodity advertised were injurious to health, of not more than $\$ 5000 .^{74}$ The purpose of this move was to give to the FTC Act the deterrent effect which the advertising provisions of the food and drug bill would have possessed. Under the bill proposed by Mr. Lea, no advertiser would have cause to fear more than an order to stop falsifying unless either his commodity were intrinsically dangerous or the government could succeed in the difficult task of proving intent to defraud.

Unfortunately for the minority committeemen, they were seeking to provide the FTC with teeth it did not want. Mr. Lea, speaking against the amendment after having "conferred with a representative of the Federal Trade Commission," said, "Its judgment is very decidedly opposed to this amendment because it would tend to be destructive of the successful operation of the Federal trade law. It would, in effect, convert the federal trade act, in effect, to a criminal statute primarily as to advertisements.... This is not the practical way to deal with business men."75

The debate was a lively one in which the record of the FTC was vigorously attacked, but the outcome seems never to have been in doubt. When the question on the bill was taken, there were-ayes, ro7; noes, $10 .{ }^{76}$

The House and Senate conferees adopted the House bill. ${ }^{77}$ When the conference report came to the Senate floor on March 14, r938, ${ }^{78}$ Senator Copeland pointed out the ulterior purpose of the House bill, but he too endeavored to strengthen its provisions. ${ }^{79}$ In the course of debate he admitted that "the House will never agree to turn over to the Food and Drug Administration the control of advertising of drugs and cosmetics."80 Without a record vote the Senate agreed to the report, ${ }^{81}$ and with that action all hope was lost for the retention of the advertising provisions in S. 5 .

For the debate, see 83 CoNG. REc. 391-424 (1938).

${ }^{73}$ See note 70, supra.

"For the text of this proffered amendment, see 83 Cong. REc. 405 (I938).

7 Id. 406.

${ }^{\text {70 } I d . ~} 424$.

$\pi$ H. R. REP. No. 1774, 75th Cong., 3d Sess. (1938).

For the consideration of the bill, see 83 Cong. Rec. $3287-3293$ (1938).

THis proposal was to extend to all commodities the special powers conferred by the bill on the FTC with respect to food, drugs, and cosmetics. Id. 3289 .

${ }^{80}$ Id. 3291 .

${ }^{81}$ Id. 3293 . 
Before this session had begun a tragedy occurred which was directly responsible for adding a new and important provision to the drug control legislation. At least 73, perhaps over 90, persons in various parts of the country, although chiefly in the South, died as a result of taking a drug known as "Elixir Sulfanilamide," manufactured and sold by the S. E. Massengill Company of Bristol, Tennessee. ${ }^{82}$ This product had been prepared in order to render the valuable new drug, sulfanilamide, available in liquid form. Diethylene glycol was used as a solvent. Investigation later showed that the pharmacist on the manufacturer's staff checked the product merely for appearance, flavor, and fragrance. Tests on animals or even an investigation of the published literature would have revealed the lethal character of the solvent. When reports of the fatalities began to appear, the F \& DA began an immediate search for the $24^{\circ}$ gallons of the product which had been distributed throughout the country. By dint of persistent and ingenious efforts the $F \& D A$, with the cooperation of other governmental agencies and dealers, was able to recover almost the entire stock distributed. Yet the only legal basis for the F \& DA's intervention was the fact that the preparation was not an "elixir" since that term may properly be applied only to an alcoholic solution. The product was therefore misbranded. The label, incidentally, did not mention the presence of the fatal ingredient, diethylene glycol.

Even if any of the bills (including S. I944) had been enacted previously it is quite possible that this disaster would have occurred, although the basis for seizure would not have had to rest on the fortuitous circumstance of choice of an inapt name for the product, since the drug would clearly have been dangerous under the conditions of use prescribed for it. Accordingly, in the brief second session, Senator Copeland introduced a bill, S. 3073, which forbade the introduction into interstate commerce of "any drug . . . not generally recognized as safe for use" under the conditions prescribed in the labeling thereof "unless the packer of such drug holds a notice of finding by the Secretary that such drug is not unsafe for use." Machinery was provided to enable the Secretary to make such a finding. A similar, but more complete, bill, H. R. 934r, was introduced in the House by Representative Chapman. Senator Copeland's bill was passed by the Senate without debate on May 5, I938.83 The Chapman bill, with minor changes, was included in the committee version of S. 5 as finally reported to the House, and in this form was enacted into law. ${ }^{84}$

Meanwhile the last major battle of the campaign was impending. The embattled apple-growers were determined not to allow the established principles of administrative law to govern the judicial review of food and drug regulations. They succeeded in persuading a majority of the House committee to report out a bill containing judicial review provisions which embodied a part of their objectives. The bill added a new procedure for the review of regulations, permitting suits to be instituted in the federal district courts within go days after the issuance of regulations to enjoin the

The story of this tragedy is told in Report of the Secretary of Agriculture on Deaths Due to Elixir Sulfanilamide-Massengill, SEN. Doc. No. 124, 75th Cong., 2d Sess. (1937), submitted in response to resolutions of both houses requesting reports on the occurrence.

$\approx 83$ CoNG. Rec. 6263 (1938).

${ }^{86}$ It is discussed at p. 40, infra. 
Secretary from enforcing them. Although the provision was silent as to the scope of the court's review, it permitted the court to take additional evidence bearing on the validity of a regulation where cause was shown for failure to adduce the evidence at the administrative hearing. ${ }^{85}$ When one considers that there are over 80 district courts in the United States and that an adverse decision by a single one of them would prevent enforcement of a regulation throughout the nation, probably for months, quite possibly for years, the drastic character of the provision becomes apparent. Moreover, this special procedure was expressly made supplemental to "any other remedies provided by law," so those affected could, if they chose, await action under the regulation before attacking it.

Six members of the committee ${ }^{86}$ joined in a vigorous minority report which incorporated a letter from Secretary Wallace written in response to an inquiry from Representatives Chapman and Mapes of Michigan ${ }^{87}$ in which the Secretary expressed the judgment that if the judicial review provision "remains in the bill its effect will be to hamstring its administration so as to amount to a practical nullification of the substantial provisions of the bill. ... It is the department's considered judgment that it would be better to continue the old law in effect than to enact S. 5 with this provision."88 The Department of Justice in a memorandum had also strongly criticized the provision. ${ }^{89}$

The Committee's action aroused even more protests from consumer sources than the Bailey Amendments had inspired. Even the Journal of the American Medical Association editorially castigated the move. ${ }^{90}$ When the bill reached the floor, ${ }^{91}$ the minority members presented their case vigorously, but apples outweighed arguments. On June $x, 1938$, the bill passed the House without amendment on this point. ${ }^{92}$

Conferees were appointed by the Senate and House respectively on June 2 and 3. On June Ir, they reported. ${ }^{93}$ As was expected, the advertising control provisions of the Senate bill were eliminated. The judicial review provision of the House bill was accepted after a revision which materially diminished the objections to that section. ${ }^{94}$

The court might instead remand the case to the Secretary. A reading of this provision, together with the comment upon it contained in the committee's report, H. R. REP. No. 2I39, 75th Cong., 3d Sess. (1937) 12, suggests that the committee doubted the constitutionality of the International Apple Association's desideratum of granting to the courts the power to judge the validity of regulations in the light of their own judgment as to the facts, but that the committee wished to shift the onus of restricting review to the courts. For I. A. A.'s position, see statement of R. G. Phillips (its secretary), House Hearings on S. $5,324-328$.

${ }_{83}$ Representatives Chapman (Ky.), O'Connell (Mont.), Mapes (Mich.), Wolverton (N. J.), Wolfenden (Pa.), and Holmes (Mass.). The minority views were reprinted in 83 Cong. Rec. 7778-7779 (1938).

${ }^{87}$ Representative Mapes was the ranking Republican member of the committee and a valiant fighter for an adequate law.

${ }^{83}$ For the text of the letter, see 83 Cong. Rec. 7779 (1938).

${ }^{80} I d .7892$.

${ }^{\infty}$ Federal Food and Drug Bill Condemned, (1938) I10 J. A. M. A. 1492.

The debate took place May 31 and June 1, I938. 83 Conc. Rec. 7771-7799, 7889-7903 (1938).

Id. 7903. A motion to recommit was defeated, 27 to 59 . Ibid.

${ }^{\infty}$ For the conference report, with a statement of the managers on the part of the House, see $H . R$. Rep. No. 2716, 75th Cong., 3d Sess. (1938), reprinted in 83 CoNG. REc. 9088-9095 (1938).

of The section is discussed at length in Fuchs, The Formulation and Review of Regulations under the Food, Drug, and Cosmetic Act, infra, p. 43. 
On the multiple.seizure limitation, a compromise was reached which, in my opinion, renders it innocuous; ${ }^{95}$ the Senate restriction on venue in multiple seizure situations was also relaxed, to the advantage of enforcement. ${ }^{96}$ With few exceptions, the other changes made for a stronger law.

The Senate agreed to the conference report without debate on June $10,1938 .{ }^{97}$ Three days later, after a flurry of protest from apple-minded Representatives, the House also agreed ${ }^{98}$ and the long fight was over. The bill was signed by President Roosevelt on June 25 , 1938 .

Before passing to a consideration of individual provisions of the new law reference should be made to the drafting process in the later stages of the bill's evolution. The activities of the drafting group which prepared S. 1944 and had shared in its metamorphosis into S. 2000 came largely to an end in 1934. However, Senator Copeland kept in constant communication with the F \& DA and consulted it in formulating amendatory provisions so as to adjust them so far as possible to its objectives. To a lesser extent the $F \& D A$ was consulted by the House Committee. Liaison between the Hill and the F \& DA was maintained chiefly through $\mathrm{C}$. W. Crawford, in charge of its enforcement activities, to whom much credit must be given for keeping the consumer protection point of view before the committees. Another person who shared actively in the drafting work from S. 2000 on was Mr. Ole Salthe who had been in charge of food and drug law enforcement under Senator Copeland when the latter was Health Commissioner of New York City. Mr. Salthe, acting as adviser to Senator Copeland, brought to the task both a realistic knowledge of enforcement problems and a lively interest in consumer welfare.

The legislative counsel of the House, Mr. Middleton Beaman, and his assistant, Mr. Allan H. Perley, were active in the revision of the bill in its last two years and succeeded in improving the measure very materially from the standpoint of form and clarity of expression. Moreover, it should not be supposed that the only amendments of value were those emanating from official sources. A number of proposals by counsel for 'companies and associations in the affected trades aided in ironing out difficulties which would have impaired compliance and enforcement, and in effecting compromises which preserved the major objectives of both groups.

\section{II}

In the succeeding portion of this article an effort will be made to indicate the content of the substantive provisions of the new Act relating to the adulteration and misbranding of foods, drugs, and cosmetics, together with a brief indication of the

\footnotetext{
${ }^{\infty}$ Multiple seizure of a misbranded article is permitted where the article has been the subject of a prior judgment favorable to the United States or where the Secretary has probable cause to believe that the article is dangerous to health or that the "labeling is fraudulent, or, would be in a material respect misleading to the injury or damage of the purchaser or consumer." \$304(a), 2I U. S. C. \$334(a).

${ }^{80}$ The claimant can move for consolidation of the cases either in any district where one of the cases is pending or "in a district of reasonable proximity to the claimant's principal place of business." \$304(b), 21 U. S. C. $\$ 334($ b). The Senate provision had located venue at the place of business.

${ }^{8} 8_{3}$ CoNG. REc. 8738 (r938).

${ }^{\infty}$ Id. 9 ror.
} 
changes which they effected in the law and the deviations in their principal terms from the provisions appearing in S. 1944, the "Tugwell Bill," and its successors. No attempt will be made to analyze in detail the provisions of the new law nor will the treatment of the legislative history of specific provisions be comprehensive. ${ }^{99}$ Not only did S. $x 944$ have a large number of lineal descendants, but each of these was subjected to a series of amendments during the course of its consideration in committee. "Committee print" followed "committee print," as many as ten such prints being required for a single bill. ${ }^{100}$ Many of the changes were primarily formal but most had some substantive significance. To trace these permutations in detail would require a monograph almost the length of this symposium, and it may be doubted whether such a treatment would be of any value save in a study of the operation of pressure groups upon pending legislation.

Precedent to a summary of the substantive provisions of the Act, it is important to explain their relation to the measure as a whole. The Act, after a preliminary chapter of definitions, contains a chapter enumerating the acts it prohibits and the penalties for violation. This chapter is discussed in detail in another article in this symposium. ${ }^{101}$ It suffices here to say that the principal act prohibited by the statute is the introduction into interstate commerce "of any food, drug, device, or cosmetic that is adulterated or misbranded." 102 The succeeding chapters comprise, essentially, definitions of what constitutes an adulterated or misbranded food, drug or cosmetic, a chapter being devoted to each commodity. ${ }^{103}$ These chapters are followed by a chapter entitled "General Administrative Provisions," a chapter dealing with imports and exports, and a final chapter entitled "Miscellaneous" grouping customary provisions relating to separability of provisions, the effective date of the Act (June 25, I939-with important exceptions), ${ }^{104}$ and the laws repealed or left unaffected by the Act's adoption.

No attempt will be made herein to trace the evolution of the advertising provisions which were ultimately excluded from the bill. However, it may be said that the provisions defining false advertising originally in S. I944 were the same as the general definition of misbranding contained in the sections defining misbranding of foods, drugs, devices, and cosmetics, and that the changes made in those sections were reflected by similar changes in the advertising sections. One exception must be made to this generalization. The section on false advertising of drugs included in S. x944, a paragraph defining as false for the purposes of the Act any advertisement of a drug representing it to have any effect in the treatment of any of 36 named diseases. ${ }^{105}$

- In some instances, I shall note arguments advanced for or against this or that change. In no instance can the discussion be exhaustive. The reader who wishes more information should consult the reports of

${ }^{100}$ See 79 Conc. Rec. 5219 (1935).
the four Congressional hearings.
${ }^{21}$ Lee, The Enforcement Provisions of the Food, Drug, and Cosmetic Act, infra. p. 70 .

$100 \$ 30 \mathrm{r}(\mathrm{a}), 2$ I U. S. C. $\$ 33$ I (a).

${ }^{100}$ Chapter IV deals with food; Chapter V, with drugs, and Chapter VI, with cosmetics. It is upon these chapters that attention will be focused in the remainder of this article.

${ }^{106}$ The provisions applicable to dangerous drugs, \$502(j), 21 U. S. C. \$352(j), new drugs, \$505, 21 id. $\$ 355$, and injurious cosmetics, $\$ 60 \mathrm{I}(\mathrm{a}), 2 \mathrm{I} i d, \$ 36 \mathrm{I}(\mathrm{a})$, took effect upon approval of the Act.

Ia) S. $1944,59(c)$. 
Power was given to the Secretary to withdraw from and add to the list of diseases by regulation. Advertisements of remedies for these diseases were excepted if disseminated solely to members of the medical and pharmacological professions and appearing in scientific periodicals. It was this section which was most often cited to prove the sinister designs of Mr. Tugwell against self-medication. In my opinion the section would have been almost equally efficacious if the list of diseases had been confined to perhaps ten ailments for which no reputable periodical would accept advertising ${ }^{\mathbf{1 0 6}}$ and the Secretary had been denied power to add to the list. Ultimately such a modification was made, ${ }^{107}$ and, thus modified, the provision would doubtless have been included in the Act if the F \& DA had been given regulatory power over advertising.

Reference should be made at this point to a distinction which is important for the understanding of the provisions of the Act, viz., a difference between the term "label" and the term "labeling." "Label" is defined to mean "a display of written, printed, or graphic matter upon the immediate container of any article" and also upon the outside container or wrapper, if any, unless this is transparent. ${ }^{108}$ With one exception, ${ }^{109}$ where the Act requires the presence of any statement for the protection of the consumer this statement must appear on the label.

"Labeling" includes "labels" but also extends to "other written, printed or graphic matter (I) upon any article and any of its containers and wrappers, or (2) accompanying such article."110 Prohibitions against misbranding by false and misleading statements relate to statements appearing on the "labeling" of the article and not merely upon its label. This differentiation, with some formal changes, was maintained throughout the succession of bills.

The requirements for affirmative disclosures on labels are reinforced by the requirement that the information appear "with such conspicuousness (as compared with other words, statements, designs or devices of the labeling) and in such terms as to render it likely to be read and understood by the ordinary individual under customary conditions of purchase and use."111 This requirement was made by S. I944, but its phrasing was improved in the course of the evolution of the measure.

In the bill reported by the House committee on April I4, 1938, there appeared for the first time in the chapter on definitions a provision of general applicability to misbranding which was included in the enacted law and which may prove one of its most important sections. This provision, Section $201(\mathrm{n})$, provides that, in determining whether labeling is misleading there shall be taken into account not only the

\footnotetext{
${ }^{100}$ Such a list would have covered $90 \%$ of the cases where the rigorous operation of this provision was important.

${ }^{10 \pi}$ The list included in S. 5 as it passed the Senate in 1935 and 1937 comprised Bright's disease, eancer, tuberculosis, poliomyelitis, venereal diseases, and heart and vascular diseases.

${ }^{100} \$ 201(k), 2$ I U. S. C. $\$ 32 \mathrm{~T}(\mathrm{k})$.

${ }^{100}$ In the case of directions for use or warnings against dangerous uses, $5502(f), 21 \mathrm{id} .5352(\mathrm{f})$, the length of the matter being normally such as to render resort to the labeling essential.

${ }_{110} \$ 201(\mathrm{~m}), 2 \mathrm{id} . \$_{321}(\mathrm{~m})$.

${ }^{11} \$ \$_{403}(f), 502(c), 602(c), 21$ id. $\$ \$_{343}(f), 352(c), 362(c)$.
} 
"representations made or suggested" but "also the extent to which the labeling fails to reveal facts material in the light of such representations or"-and this seems to me especially significant-"material with respect to consequences which may result from the use of the article ... under the conditions of use prescribed in the labeling ... or such ... as are customary or usual." This provision constitutes not only a guide to the F \& DA and the courts in the interpretation and application of the Act but also a warning to the industries that informative labeling is essential to safety from prosecution or seizure. Reference to this provision will be made in connection with those other sections which it serves to supplement most importantly.

With respect to a number of label requirements the Secretary is given power to make regulations exempting products from the requirement either where compliance is not necessary for the public health or where it is impracticable. ${ }^{112} \mathrm{~A}$ broader exemption provision confers power on the Secretary to exempt by regulation goods in transit between processing and packing establishments, the exemption to be conditioned upon compliance with the Act when the goods are removed for distribution. ${ }^{113}$

It is, of course, inaccurate to say that any section merely defining adulteration or misbranding prohibits the adulteration or misbranding defined. Since, however, strict accuracy of expression would be costly in words, in the discussion which follows I have referred at times to these sections as prohibiting offenses of which they merely define a basic element.

\section{Food}

I. Definition. The definition of "food"114 was subject to complete revision during the evolution of the Act, but the changes were of a formal character only.

2. Food Definitions and Standards. No authorization was given in the Igo6 Act for the establishment of definitions and standards of identity for foods, ${ }^{115}$ but since it is an intellectual impossibility to determine, without reference to some definition or standard, whether a food is adulterated or misdescribed in a label, the F \& DA found it essential to set up administrative definitions and standards of identity. These did not have the force and effect of law and, in the case of contest, a different criterion from that fixed by the F \& DA could be urged by the defendant. The new Act ${ }^{118}$ authorizes the fixing of definitions and standards of identity having the effect of law and thereby greatly simplifies enforcement of provisions dependent thereon. The only major objection to this provision came from fruit and vegetable interests who protested that such standards were not necessary for their products and might create conflict with state grading and standardizing laws. The point was carried, and exception made of all such products except avocadoes, cantaloupes, citrus fruits, and

${ }^{119}$ Reference will be made to these exemptions in connection with the sections which they qualify.

11s $\$ \$ 405,503(\mathrm{a}), 603,2$ I U. S. C. $\$ \$ 345,353(\mathrm{a}), 363$.

IIs $\$ 201(f), 21$ id. $\$ 321(f)$ : "( $(1)$ articles used for food or drink for man or other animals, (2) chewing gum, and (3) articles used for components of any such article."

${ }^{115}$ A special statutory standard of identity for butter was enacted in 1923. 42 STAr. I500 (1923), 21 U. S. C. \$6. This was left intact by the new Act. \$902(a), 21 id. $\$ 392(a)$.

116 \$40I, 21 id. \$34 . 
melons, as to which the Secretary was empowered to fix definitions and standards of identity relating only to maturity and the effects of freezing.

Reference has already been made to the issue raised by the provision in S. 1944 authorizing the establishment of more than one standard of quality for any given food. In 1930, the McNary-Mapes Amendment had authorized the fixing of one such standard for canned foods, products falling below the standard being required to indicate that fact on the label. ${ }^{118}$ No opposition arose to the extension of this provision to all foods (except from the fresh fruit and vegetable producers whose opposition prevailed to the degree noted above) but the grant of power to establish what in effect would be a government grading system for food products was bitterly fought. Victory was won by the opposition as early as S. 2800 in 1934, and the enacted law permits the establishment only of "a reasonable standard of quality."119

The chief grounds of attack were twofold: (I) Multiple standards of quality could not be based on objectively determinable criteria and hence enforcement and compliance would alike be impracticable. (2) Such standards were economically disadvantageous as destroying the guidance to the consumer of established and respected brand names, ${ }^{120}$ and as ruinous to the good will of the producers of such brands, and as detrimental to publishers dependent on brand name advertising.

That no small measure of truth inhered in the first ground of objection cannot be denied. The only answer that could be made was that the promulgation of standards would have to proceed only as fast as objectively determinable criteria were developed. A requirement that standards be of this character was actually written into S. 2000. ${ }^{121}$ The second objection raised an issue of values on which difference of opinion was inevitable, even in the industry itself where the rivalry of "national" and "private" brands has led to controversy in a variety of fields. The victory of the "national" brands and their publisher allies represents the only major defeat of the proponents of the bill in the food field. But with the continuation of consumer interest in grading of food products, it seems safe to predict that the end is not yet.

Authority to promulgate standards of fill of containers was also written into the new Act, ${ }^{122}$ with safeguards to assure recognition in such standards of natural shrinkage and of protective packing. Argument centered chiefly on the scope and phrasing of these safeguards.

117 lbid.

${ }^{115} 46$ STAT. IoIg (I930), 2 I U. S. C. SIO, "Foods," par. 5.

20 The same phrase was used in the McNary-Mapes Amendment. Foods falling below the standard are, roughly, those which might be rated " $D$ " in a grading system. They are wholesome and not adulterated. The Amendment limited the classes for which standards might be set to "generic" classes. The new Act omits this restriction but directs the Secretary to make "due allowance" for "the differing characteristics of the several varieties of such fruit or vegetable."

${ }^{100}$ It was argued that competitive considerations would compel producers to hold their products down to the minimum demanded for compliance with a given grade, since consumers would assume that all products of that grade were identical in quality.

17 5Ir. Unless the criteria used were of this character the provision would probably be unconstitutional by reason of uncertainty. The F \& DA, in enforcing the McNary-Mapes Amendment, had developed a number of ingenious testing devices for solving this problem.

$19 \varsigma_{40 r, 2}$ I U. S. C. $\$_{34}$. 


\section{Adulteration of Food}

a) Poisonous, Insanitary, Etc., Ingredients. The prohibitions against any food containing a poisonous ingredient which may render it injurious to health and those against insanitary ingredients were carried over with little change from the old Act. The chief additions made by S. 1944 (which were preserved without significant change ${ }^{123}$ ) were designed to prohibit foods containing poisons naturally present as well as added poisonous ingredients, foods prepared or packed under such conditions as might render them contaminated or otherwise injurious, and foods packed in containers so composed that they might render the contents injurious.

b) Tolerances for Unavoidable Poisonous Ingredients. The section discussed in the preceding paragraph is directly linked to the section ${ }^{124}$ authorizing the Secretary to establish tolerances for unavoidable poisonous ingredients in foods by a clause in the former prohibiting the presence of added poisonous ingredients if declared "unsafe" by regulation under the latter section. The section defining the Secretary's powers was constantly revised during the evolution of the measure, but in the end did not greatly differ from that in S. $1944 .{ }^{125}$ The major battle arising from this provision was fought on the issue of judicial review and was described earlier in this article.

c) Absence, Substitution or Addition of Constituents. This section ${ }^{128}$ strengthened the old Act chielly through the addition of a broad clause prohibiting the introduction of any substance added to make "the product appear better or of greater value than it is," a more rigorous restatement of the like clause in S. $x 944,127$ ". . . or create a deceptive appearance," which had aroused some apprehension by reason of its generality.

d) Uncertified Coal-Tar Coloring. This section ${ }^{128}$ prohibits the use in food products of coal-tar coloring except where the colors have been listed in regulations as harmless and come from batches certified by the $F \& D A$ under authority conferred by another section. ${ }^{128}$ These sections give legal sanction to a practice developed by the F \& DA without statutory authority, which had proved beneficial to all interested parties.

e) Confectionery containing Alcohol or Non-nutritive Substances. The old Act listed certain non-nutritive substances and alcohol, the presence of which would render the product adulterated. ${ }^{130}$ This list was inadequate, especially in that it failed to cover the practice of placing tiny toys and trinkets in children's candy, which may cause injury or death when swallowed. The new provision ${ }^{131}$ bars alcohol (up to $.5 \%$ ) and non-nutritive substances except harmless coloring, flavoring, resinous glaze (up to $.4 \%$ ), natural gum and pectin. The principal controversy arose as to the last three ingredients, and the present provisions as to them represent a

\footnotetext{
$12 \$ 402(\mathrm{a}), 21$ id. $\$ 342(\mathrm{a})$.

$221 \$ 406(\mathrm{a}), 21$ id. $\$ 346(\mathrm{a})$.

$20 \$ 402$ (b), 21 U. S. C. $\$ 342(b)$.

$228 \$ 402(d), 21$ U. S. C. $\$ 342$ (d).

250 \$8, "Confectionery," 21 id. $\$ 8$.
}

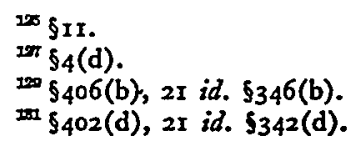


concession from S. 1944. To preserve the status of chewing gum, a proviso was added permitting the use therein of harmless non-nutritive masticatory substances.

\section{Misbranding of Foods}

a) False or Misleading Labeling. The brief provision ${ }^{\mathbf{1 3 2}}$ declaring a food misbranded if its labeling is "false or misleading in any particular" repeats the language of the old Act. ${ }^{133}$ The language of S. $1944^{134}$ which aroused the bitter criticism described earlier in the article, was intended, and doubtless would have been held, to mean the same as the language finally retained, especially when that language is read in the light of Section $201(n) \cdot{ }^{135}$ Persistent efforts were made to introduce qualifying terms into this definition, e.g., "material" 'before "particular."130 It is not improbable that the Act will be interpreted and administered as if many of the various qualifications proposed were present in its language. But, had they been expressed therein, they would have constituted an invitation to laxity in compliance. Moreover, defense counsel would have utilized them to great advantage in persuading juries to regard misleading statements as inconsequential. ${ }^{137}$ They gained admission to none of the reported bills. ${ }^{138}$

b) Provisions Relating to Identity and Ingredients of Foods. Deception with respect to foods is most frequently effected through creating the impression that a product is a commonly-known food when it does not in fact contain the ingredients which may properly be expected of that food. The tactic may result in both adulteration and misbranding. Suppose tea-seed oil is added to olive oil and the mixture labeled "olive oil." Here both offenses are clearly present. Yet tea-seed oil is harmless and its presence cannot easily be detected. It should be possible to market such a compound so long as the public is not deceived.

The old Act had sought to escape this difficulty by providing that harmless "mixtures or compounds" might be offered for sale under their own "distinctive names," provided that an article was not "an imitation of or offered for sale under the distinctive name of another article" and, in the case of a compound, imitation or blend of foods not sold under a distinctive name, that the world "compound," "imitation" or "Blend" plainly appear on the label.130

This solution provided a convenient loophole for evasion of the Act. To return

${ }_{100} \$ 403(a), 21$ id. $\$ 343(a)$.

2300 58, "Food," par. 4, 2x id. 510.

134 "If its labeling is in any particular false, or by ambiguity or inference creates a misleading impression ..." \$6(a).

${ }^{135}$ For a quotation from this section, see pp. 24-25, supra.

${ }^{100}$ Another qualification which received considerable support was that appearing in the McCarranJenckes bill, S. 2858, 73d Cong., 2d Sess. (1934), 55(a): "(I) If its label is false in any particular; or (2) if its label, while not false, is actually or injuriously misleading to the purchasing public, in any particular." (Italics added.)

25. The dangers in such language are presented more fully in Cavers, Letter to the Editor (1934) 166 Printers' Inx, No. I, P. 21; Handler, The Control of False Advertising under the Wheeler-Lea Att, infra, at pp. 97-ror.

${ }^{283}$ The definition of "false advertising" in S. 5 as it passed the Senate in 9935 added after "particular" the following: "relevant to the purposes of this Act regarding such food, drug, or cosmetic." S. 5, 74th Cong., $2 d$ Sess. (1935) $\$ 601$ (a). This was omitted from S. 5 in 1937.

${ }^{20} \$ 8$, "Foods"; 2 I U. S. C. \$ro. 
to the example given above, adulterated olive oil could be sold as, say, "Spanola-For Salads," in an olive-hued can resembling those used for genuine olive oil, and an undiscriminating public would purchase it without any awareness that the distinctive name meant an inferior product. The effort to meet tactics of this sort resulted in the inclusion in the new Act of a number of provisions directed against misbranding in order to supplement those prohibiting adulteration.

The offering of one food for sale under the name of another is prohibited, unless clearly marked "imitation."140 If a statutory definition and standard of identity is fixed by regulation for a food, then a product which "purports to be or is represented as" such food must meet the criteria prescribed.14I Clearly the olive and tea-seed oil mixture would not meet any definition of identity which might be fixed for olive oil, and, if labeled "olive oil" (omitting "imitation") would be in violation of the provision. However, in the case of the hypothetical "Spanola," there would be a difficult question whether it purported to be, or was represented as, olive oil. But if it were not deemed subject to this provision, then clearly it would be subject to the new provision $^{142}$ requiring that a fabricated food for which no definition and standard of identity has been prescribed must be labeled with "the common or usual name of the food, if any there be" and of each ingredient it contains (spices, flavorings, and. colorings being designated generically). Thus, "Spanola," if deemed not to be offered as olive oil, would have to bear a label stating the presence of its two ingredients, olive oil and tea-seed oil.

Where a standard of quality is fixed for the food, then a food falling below that standard must be labeled as sub-standard or be held misbranded. ${ }^{143}$

All the foregoing provisions were included in substance in S. $1944 .{ }^{144}$ The section requiring the label declaration of ingredients of non-standardized, fabricated foods was the source of greatest controversy. In its original form this requirement called for the listing of ingredients "in order of predominance by weight."145 The opposition, in which "Ovaltine" was prominent, insisted that the provision had no consumer value, that compliance in cases of shifting ingredients would be impracticable, and that competitors would utilize the disclosure to appropriate good will earned by established products. Proponents of the measure argued that not only was the provision important for the protection of the consumer against fraud but also that it had

\footnotetext{
${ }^{200} \$ 403$ (b), (c), 21 id. $\$ 343$ (b), (c). The word "imitation" must immediately precede the name of the food imitated and be in letters of the same size and prominence.

$14 \S_{403}(\mathrm{~g}), 2 \mathrm{I}$ id. $\S_{343}(\mathrm{~g})$. The label must bear the name of the food prescribed in the regulation. This provision may be important. As definitions and standards of identity are extended into the increasingly important field of fabricated foods, the use of the prescribed name will diminish the seductiveness of names coined to make the ordinary seem unique.

Where the definition permits the use of certain optional ingredients, as authorized in $\$ 40 \mathrm{r}, 2 \mathrm{I} i$. $\$ 34 \mathrm{r}$, the regulation may require a label declaration of their presence.

$10 \$ 403(\mathrm{i}), 21 \mathrm{id} . \$ 343(\mathrm{i})$. A proviso authorizes the Secretary to make exemptions from the listing requirement where compliance "is impractical, or results in deception or unfair competition."

${ }_{163} \$ 403(\mathrm{~h})(\mathrm{r}), 2 \mathrm{I}$ id. $\$ 343(\mathrm{~h})(\mathrm{r})$. The fact that the product is substandard must be stated as prescribed in the regulation.

14 As has been stated, S. 1944 made provision for more than one standard of quality.

${ }^{145}$ S. $1944, \$ 7(f)$.
} 
value from a public health standpoint; that the countless sufferers from allergies should have a means of knowing what was contained in the food sold to them. The opposition never secured more than the excision of the clause as to the order of naming ingredients, a requirement of some value to the consumer but adding greatly to the burden of compliance and enforcement. ${ }^{148}$

No special provision was contained in S. x944 requiring declaration of the presence of artificial flavors, colors, and preservatives, reliance being placed on other provisions to achieve that end. In I935, however, such a requirement was wisely introduced in S. 5, and, with minor modifications, was included in the enacted law. ${ }^{147}$ The practice of coloring oranges with coal-tar dyes gave rise to lively sectional strife between Florida (where it prevailed) and California whose citrus fruit growers were happily able to protect at once both the consumer and their natural competitive advantage. ${ }^{148}$

c) Food for Special Dietary Uses. With the requirement that ingredients of fabricated foods be disclosed, S. I944 coupled a broad grant of power to the Secretary to require by regulation "such further information" on labels "as he may deem necessary to protect the public from deception." In S. 2000 this power was narrowed and directed against the specific field where the need for it was greatest: foods offered for special dietary uses. The revised provision was retained in substance in the enacted law. The Secretary may by regulation require label disclosure of information concerning the "vitamin, mineral, and other dietary properties" of any such food where "necessary in order fully to inform purchasers as to its value for such uses."148"

d) Provisions as to Containers. Packaged foods were required by the old Act, as amended, to state the quantity of the contents "plainly and conspicuously" on the package "in terms of weight, measure or numerical count."148 Advantage was taken of the consumer's tendency to judge quantity by the size of the package rather than by the printed declaration, by slack-filling large packages or using misleadingly de. signed containers, tactics against which the F \& DA was powerless. ${ }^{150}$ The new Act declares a food misbranded "if its container is so made, formed, or filled as to be misleading."151 The requirement of declaration of quantity is preserved, but to it is added the new requirement that the label bear "the name and place of business of the manufacturer, packer, or distributor."162 Authority is also given to the Secretary

\footnotetext{
${ }^{210}$ Quaere, whether the addition of a minute quantity of a valuable ingredient to render the list more impressive, without disclosure that the quantity added was nominal, would not render the label declaration misleading in view of $\$ 201(n), 21$ U. S. C. $\$ 321(n)$, quoted supra, pp. 24-25. Cf. note I42, supra.

${ }_{272} \$_{403}(\mathrm{k}), 2 \mathrm{U}$ U. S. C. $\$_{343}(\mathrm{k})$. The Secretary is empowered to make exemptions where compliance is impracticable. Butter, cheese, and ice cream are relieved of the obligation to declare artificial coloring.

as Dyed Florida oranges will have to be stamped "Color Added" or be in violation of both this section and the adulteration section forbidding the addition of substances to make 2 "product appear better . . . than it is." $\$ 402(b)(4), 21$ id. $\$ 342(b)(4)$. The "ethylene gas process" which hastens bringing the fruit to its natural color will be legal, however.

160 $\$ 403(j), 21$ U. S. C. $\$ 343(j)$.

${ }^{150}$ For examples, see Lamb, AMerican Chamber of Horrors, c. 7.

1903 (d), 2 I U. S. C. $\$ 343$ (d).

200 $\$ 403(c), 21$ id. $\$ 343($ c). Reasonable variations shall be permitted, and exemptions granted to small packages, by regulation, as was the case under the old Act.
} 
to prescribe standards of fill of containers, ${ }^{153}$ and deviation from any such standard constitutes misbranding, unless disclosed. ${ }^{154}$

5. Emergency Permit Control. Although the provision in the new law giving power to the Secretary to establish a licensing system for the interstate shipment of food produced under certain circumstances is discussed in another article in this symposium ${ }^{155}$ brief reference will be made to it here. In the administration of the old Act the F \& DA had found difficulty in coping with situations which occasionally arose in which food products, notably crabmeat and oysters, had become contaminated by micro-organisms during processing and packing. The rapid distribution of the product made it virtually impossible to inspect and seize contaminated products after shipment. Accordingly a provision was inserted in S. $1944^{158}$ authorizing the Secretary, in such situations, to issue regulations governing the conditions of manufacture, processing, and packing necessary to protect the public health and requiring establishments subject to those regulations to hold permits conditioned on compliance therewith. Despite the restricted function of this provision, it was viewed by the food industry with many misgivings. These were allayed by revisions of the section rendering more specific the conditions under which the power could be exercised, without, however, impairing the efficacy of the provision in the situations where its use had been contemplated. Thus revised, the section was enacted. ${ }^{157}$

S. $x 944$ also provided ${ }^{158}$ that the Secretary might, in his discretion, establish a "voluntary inspection service" at the plant of any producer (of foods, drugs, or cosmetics) applying therefor. Inspected products might be marked to show conformity to the Act. Costs of inspection were to be met by fees. This provision aroused vigorous opposition. Once some producers were granted the service, it was argued, competition would require others to adopt it. The opposition brought about the exclusion of the provision from S. 2000. I do not regret the step for the section was an inadequate basis for an undertaking of the magnitude it envisaged. Provision for service of this sort should be devised for specific industries and extended to them as the need develops. The 1934 Seafood Amendment ${ }^{159}$ exemplifies the preferable procedure.

\section{Drugs and Devices}

I. Definitions. The definition of "drug" in the old Act ${ }^{180}$ was defective in two respects. It did not cover ( $x$ ) products designed to affect the structure or functioning of the body where disease was not involved ${ }^{161}$ or (2) mechanical devices used either for such purposes ${ }^{162}$ or in the diagnosis or treatment of disease. ${ }^{163}$ Consequently the

\footnotetext{
$200 \$_{401}$, 21 id. $\$ 34 \mathrm{I}$. In I930, this power was given, as to canned foods, by the McNary-Mapes Amendment, supra note $\mathrm{r} 8$.

${ }^{154} \$_{403}(\mathrm{~h})(2), 21$ id. $\$ 343(\mathrm{~h})(2)$.

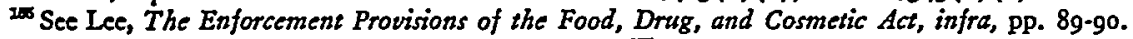

180 $\Upsilon_{12}$.

I5* 922 .

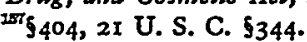

23048 STAT. 2204 (1934), am'd, 49 STAT. 871 (1935), 2 I U. S. C. A. $\$ 3722$ (Supp. 1938). This is described in Lee, supra note 155 , at p. 88 , infra. The service has functioned successfully in the shrimppacking industry, and provision is made for its continuance in the new Act. $\$ 902(2)$, 2I U. S. C. $\$ 392(2)$. 10056,21 id. $\$ 7$.

1E E.g., nose and limb "straighteners."

${ }^{201}$ E.g., obesity "cures."

${ }^{100}$ E.g., diathermic devices.
} 
F \& DA was powerless to combat a host of both types of products which appeared on the market under misleading claims and which in some instances were positively dangerous to the user. Accordingly the term "drug" was redefined in S. I944 so as to include these products. The simple tactic, far from uncommon in statutory definition, of giving a special meaning to an ordinary term, evoked unexpected opposition, ${ }^{104}$ and ultimately separate definitions were provided for "drug" and "device." introduction of the provision regulating the use of new drugs required a special definition for the term "new drug."168

\section{Adulterated Drugs and Devices ${ }^{187}$}

Under the old Act a drug was adulterated only if its "strength or purity" fell below the "professed standard or quality" under which it was sold ${ }^{168}$ or, in the case of "a drug sold under or by a name recognized in the U. S. Pharmacopoeia or National Formulary," if the drug differed from the "standard of strength, quality or purity as determined by the test laid down" in the appropriate work. ${ }^{160}$ However, a drug defined in either of these "official" compendia ${ }^{170}$ was not adulterated if a standard different from that contained in the compendium was plainly stated on the container. and the drug met that standard. ${ }^{171}$

These provisions were inadequate in several respects to achieve their purpose of assuring uniformity in standard drug products. ${ }^{\mathbf{1 7 2}}$ In the first place, the Homoeopathic Pharmacopoeia was omitted, and hence homoeopathic drugs were not accorded this protection. This omission was corrected in S. 2000 and succeeding bills. ${ }^{178}$ The provision enabling a manufacturer to deviate from the official standard provided he merely set forth the standard which he had adopted did much to destroy the efficacy of the section. The disclosure of the standard adopted was meaningless unless the

${ }^{14}$ Osteopaths and chiropractors, licensed to use devices but not drugs, professed great alarm. Senator Clark found the definition "ridiculous, absurd, and asinine." 79 CoNG. REc. 4844 (1935).

100 "Drug," \$20I (g), 2 I U. S. C. \$32I (g); "Device," \$20I(h), 21 id. \$321(h).

${ }^{100}$ A "new drug," \$20r (p), 21 id. \$32I (p), is a drug (r) which has not become generally recognized by qualified experts as safe for use under the conditions of use indicated in its labeling (excepting any drug previously subject to the Act as regards conditions of use for which it then had been represented) or (2) which has been found safe in investigations but which has not been actually used for a material extent or time under the conditions of use indicated.

107 The term "drug" will be used hereinafter to refer to both drugs and devices. However, "devices" are not covered by certain of the provisions, discussed below, relating to pharmacopocial products, adulteration by admixture of ingredients, habit-forming substances, declaration of ingredients, packaging, deteriorating drugs, and new drugs.

100 \$7, "Drugs," par. 2, 21 U. S. C. \$8. $\quad 200$ Id. par. I.

270 The term "official compendium" was adopted as a means of convenient reference to these works and is defined in the new Act to mean the United States Pharmacopocia, the Homoeopathic Pharmacopocia, and the National Formulary, and their supplements. \$20I(j), 2I U. S. C. \$321(j). They are the publications of unofficial bodies, however, and the constitutionality of giving legal effect to their stanciards has been questioned. See Hoge, An Appraisal of the New Drug and Cosmetic Legislation from the Viewpoint of those Industries, infra, at pp. II7-118.

277 77, "Drugs," par. 2, 21 U. S. C. \$8. Where a drug is recognized in both the U. S. and the Homoeopathic Pharmacopocias the standards of the former are to be applied unless the drug is sold as a homocopathic drug.

172 U. S. P. drugs "represent from 70 to 80 percent of the medicines prescribed by physicians in the United States today." Testimony of Dr. E. F. Cook, Chm., Committee of Revision, U. S. P., Hearings on S. 2800 , at 188 .

${ }^{13}$ See note 170, stipra. 
person using the product could check the standard disclosed against the Pharmacopoeia or Formulary. Accordingly, the requirement was made in S. 1944 and carried into the law that the label show wherein the drug differed from the official standard..$^{174}$

The third weakness lay in the fact that the tests prescribed in the compendia by which compliance with their prescribed standards of strength, quality, and purity were to be determined, were often inadequate for enforcement purposes, especially in that they did not always reveal deviations from the official formula or descriptions of the drugs to be tested. Hence a drug which, by the prescribed tests, would meet the prescribed standards, might be made of different ingredients than those called for in the official formula. Advantage had been taken of this situation by manufacturers, sometimes to utilize cheaper ingredients, often to differentiate. their products from the standard so as to afford basis for claims of improvement. Some of these changes did constitute improvements; others were of little or no consequence; and there was always the possibility that the new ingredients would not have the same physiologic effects as the old.

To assure the advantage of standardization, it was thought necessary to compel drug manufacturers to choose either to comply with the official formulae as well as standards or to cease offering their deviating products as official drugs. Accordingly, S. 1944 contained a provision requiring compliance, in the case of official drugs, with the official formulae or descriptions as well as with the prescribed standards.175 Further, it authorized the Secretary to establish by regulation new tests and methods of assay where those prescribed were found insufficient. ${ }^{176}$

The principal attack on these provisions was directed to the requirement that a drug meet the official description or formula. The Parke-Davis Co., whose views were pressed by Senator Vandenberg, ${ }^{177}$ led the opposition which, however, did not include all the pharmaceutical manufacturers. ${ }^{178}$ Ultimately the offending clause was stricken from the bill, but only minor changes were made in the rest of the section. ${ }^{178}$ Whether the deletion of this clause will be consequential depends on the interpretation to be placed on a succeeding provision which defines as adulterated a drug in which "any substance has been ... substituted wholly or in part therefor."180 This provision, not in the old Act, may be held applicable where it can be shown that new ingredients have been substituted in standard drugs for those prescribed in the official formulae.

In addition to the above requirements the definition of adulterated drugs and

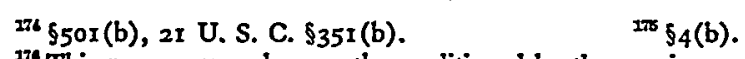

120 This power was subsequently conditioned by the requirement that the Secretary first request revision of the appropriate publication board and that it fail to act within a reasonable time. \$50r(b), 21 U. S. C. 535 I (b).

${ }^{2 \pi}$ Senator Vandenberg even introduced an amendment which would have relieved the manufacturer from stating wherein the drug differed from the official standards of strength, quality, and purity, but the amendment was rejected. 79 Cong. Rec. 4907-4910 (I935).

${ }^{170}$ See, e.g., testimony of J. P. Styder, Norwich Pharmacal Co., Hearings on S. 2800, at I49; cf. brief of Dr. J. F. Anderson, E. R. Squibb \& Sons., id. at 616.

${ }^{270}$ For one such change, see note 176 , supra. $\quad 250 \$ 50$ I (d), 21 U. S. C. $\$ 35$ I (d). 
devices is extended to cover products containing insanitary ingredients, prepared under insanitary conditions, or packed in containers composed of any poisonous or deleterious substance which may render the product itself injurious. ${ }^{181}$ Coal-tar colors used for coloring purposes must be certified..$^{182}$

\section{Misbranding of Drugs and Devices by False or Misleading Labeling}

The new Act ${ }^{183}$ preserves the broad definition of misbranding contained in the old Act, ${ }^{184}$ viz., "false or misleading in any particular." S. I944 had utilized for drugs the same definition of falsity that aroused so much opposition in the case of foods, ${ }^{185}$ but this language was eliminated in S. 2000 and the clause set forth above substituted. In the old Act, however, this definition was supplemented by a special requirement, applicable to therapeutic claims, which had been added in Igr2 by the Sherley Amendment and which compelled proof that claims were both "false and fraudulent."186 This provision in effect accorded a license to the ignorant nostrum vendor who sold inefficacious drugs in good faith. Moreover, fraud is always difficult to prove, and the $F \& D A$ was driven to elaborate investigations and costly trials to secure even the seizure of drugs for which outrageous label claims were made. ${ }^{187}$ But since the truth or falsity of therapeutic claims must often rest on opinion evidence and since expert opinion may differ, it was felt essential to provide a criterion of opinion evidence sufficiently definite to avoid the risk that the provision would be held unconstitutional for want of certainty. ${ }^{188}$ In S. I944, therefore, the general definition of misbranding was supplemented, as to drugs, by the following: "if its labeling bears any representation, directly or by ambiguity or inference, concerning the effect of such drug which is contrary to the general agreement of medical opinion."189 Where no such agreement existed, of course the government's burden of proof could not be sustained. With respect to most claims which called for prosecution, general agreement could normally be anticipated, but recognition of the fact that, as to new products, medical opinion might not have crystallized, resulted in the addition, in S. $2000,{ }^{190}$ of an alternative criterion, "demonstrable scientific facts." This was retained in S. 5 as introduced in 1935, and passed by the Senate that year with minor changes. ${ }^{191}$ In S. 5, r937 model, however, the provision was completely eliminated and did not reappear in the bill.

${ }^{134}$ \$5OI (a), 21 id. \$35I(a).

250 16id.

284 $\$ 8,21$ id. $\$ 9$.

${ }^{185} 37$ STAT. 416 (1912), 21 U. S. C. \$ro, "Drugs," par. 3.

128 $5502(a), 21$ id. $5352(a)$.

1505 See note 134, supra.

287 An outstanding example was the "B \& $M$ " case which cost the government $\$ 75,000$ and took ten years time to drive fraudulent tuberculosis claims off the label of a medicament which, starting its career as a horse-liniment, evolved into a "cure" for almost all conceivable human ills. The case is graphically described in Lama, American Chamabr of Horrors, 40-58.

${ }^{183} \mathrm{~A}$ line of Supreme Court cases indicate that a statute subjecting a person to criminal liability for making claims as to which there exists a genuine difference of opinion would be held unconstitutional. U. S. v. Johnson, 221 U. S. 488 (r91I); Seven Cases Eckman's Alterative v. U. S., 239 U. S. 510 (1916); cf. American School of Magnetic Healing v. McAnnulty, 187 U. S. 94 (I902).

$10058(a)$ (2).

${ }^{100} \S 6(2)$. 
Concern was not felt that this omission would cause constitutional objection in cases where medical opinion agreed, or scientific fact demonstrated, that the claims at issue were false, but the risk that the defendant might produce one or two experts whose opinion ran counter to the great weight of scientific opinion was still present. The inclusion of Section 201 (n) in S. 5, as reported by the House committee in I938, was thought to meet this difficulty. That section, as may be recalled, ${ }^{192}$ requires disclosure of those material facts essential to prevent representations from being misleading. Where claims for a product are not generally supported by medical opinion, the fact that some expert opinion supports them will prevent them from being held false, but unless the prevailing opinion contrary to those claims is disclosed, the labeling can properly be regarded as misleading. Through full disclosure the manufacturer can protect himself against the uncertainties of opinion evidence-and in so doing protect the public as well. ${ }^{193}$

A further requirement as to therapeutic claims was made in S. 1944. Drugs are all too frequently labeled "for the treatment of" or "for use in cases of" diseases named on the label when the only efficacy the drugs have with respect to the named diseases is in the palliation of symptoms, "often minor ones. Yet the label statement is not false and cannot easily be proved to be misleading. If the sufferer is to be protected from reliance upon a palliative which he believes to be a cure for the disease named, some affirmative disclosure of the limitations of the drug's effect is necessary. This protection S. I944 sought to afford by providing 194 that "if the labeling bears the name of any disease for which the drug is not a specific one but is a palliative," then the drug is misbranded if its labeling "fails to bear in juxtaposition with such name and in letters of the same size and prominence a statement that the drug is not a cure for such disease."

The protests against this provision were equalled in poignancy by those aroused by few other sections. ${ }^{195}$ It was pointed out that few drugs were specific cures and that hence the requirement would be applicable to most products. The trade feared that the public would infer from the statement that the drug was not a cure that it was therefore valueless. The requirement as to the size and place of the statement was attacked as impracticable.

This outcry led to a modification in S. 2000, the affirmative disclosure required being "a plain and conspicuous statement, so placed as to be readily observable where such name occurs, indicating that the drug is a palliative and how the palliation is effected." ${ }^{86}$ This change palliated but did not cure the opposition to the measure.

100 See pp. 24-25, supra.

108 The point is fully discussed in the 1938 House committee report on S.5. H. R. Rep. No. 2139, 75 Cong., 3d Sess. (1938) 7-8. Cf. the reports on the comparable provision in the Wheeler-Lea Act, $H$. R. Rep. No. 1613, 75th Cong., Ist Sess. (1937) 7-8, and No. 1774 (Conft Rep.), 75th Cong., 3d Sess. (1938) 10. See Handler, The Control of False Advertising under the Wheeler-Lea Act, infra, pp. 100-102. $104 \$ 8(a)(I)$.

300 The same provision was contained in the section defining false advertising. $\oint_{9}(b)(x)$. These provisions, especially the latter, were the most drastic in the bill, in my opinion. Less harsh provisions directed to the same end would have been wiser. $\quad 100$ \$8(a). 
It was insisted that to describe the method of palliation would necessitate the incorporation of treatises on physiology in the labeling. This led to a substitution in S. 2800 of "the nature of its palliative action"197 for "how the palliation is effected." The entire provision had disappeared from the bill when S. 5 was introduced in 1935.

How serious this loss will prove will again depend in considerable measure on the construction placed by the courts upon Section $201(n)$. If they are willing to hold that the offering of a drug for the treatment of a named disease for which that drug has only minor palliative effects constitutes misbranding when the limits of the drug's efficacy are not disclosed, then the major objective of the provision will be achieved. If only the most flagrant cases move the courts to such action, the consumer will continue to be misled on a serious scale. Yet obviously the provisions in S. 2000 and S. 2800 would have created such difficulties in enforcement as to have required the adoption of a very liberal standard of compliance. ${ }^{108}$ Possibly the requirement would have been held invalid for uncertainty.

\section{Misbranding of Drugs and Devices by Failure to Make Required Disclosures on Labels}

a) Habit-Forming Substances. The old Act required label disclosure of the quantity or proportion in any drug of twelve listed ingredients or their derivatives. ${ }^{100}$ The list comprised alcohol, several opiates and other narcotic drugs, and acetanilid, a heart depressant used in pain-killers. The Harrison Anti-Narcotic Act in effect supplanted the provision as to most of the listed drugs, but meanwhile public consumption of a number of coal-tar products, more accurately classified as hypnotics than narcotics, had grown to alarming proportions. There is a tendency for the use of these drugs to become habitual, and excessive use produces serious physiological effects. In S. 1944, therefore, the list was broadened, and, to avoid its obsolescence, power was given to the Secretary to add to it. ${ }^{200}$ Moreover, since the mere statement of the presence of the drug, although of value to the physician, seldom gave warning to the user, a requirement was added that products containing any of the listed ingredients be labeled "Warning-May be Habit-Forming."

Opposition to this section centered chiefly on the powers to be conferred on the Secretary. By the time S. 5 passed the Senate in 1935, he was stripped of the power to add other substances to the list and this power was never restored. However, as to existing drugs, the list ${ }^{201}$ in the enacted law ${ }^{202}$ is probably comprehensive, and, $197 \$ 8(\mathrm{a})$.

${ }^{100}$ The problem illustrates the difficulty of imposing affirmative disclosure requirements without establishing administrative machinery to pass in advance on the conformity of the disclosure to the statutory standard. Compare the mechanics for the assurance of full disclosure under the Securities Act.

100 §8, "Drugs," par. 2, 21 U. S. C. \$10.

$200 \$ 8(\mathrm{~b})$. This provision applied only to drugs "for internal use by man."

201 Alpha eucaine", barbituric acid, beta eucaine*, bromal, cannabis", carbromal, chloral*, coca, cocainc", codeine, heroin", marihuana, morphine", opium", paraldehyde, peyote, sulphonmethane, or "any chemical derivative of such substance, which derivative has been by the Secretary, after investigation . . . designated as habit-forming." $\$ 502$ (d), 2 I U. S. C. $\$ 352$ (d). The asterisk denotes drugs listed in the old Act. Alcohol, chloroform, and acetanilid, listed in the old Act, were transferred to the provision, infra note 207, requiring ingredient disclosure of non-official drugs.

${ }_{200}$ This provision (and certain others) is subject to a qualification contained in a later section, $\$ 503$ (b), 21 id. $\$ 353(\mathrm{~b})$, exempting these drugs from the required label disclosure where they are dispensed on 
as to future drugs, considerable protection is afforded by other sections of the new Act. ${ }^{203}$

b) Ingredients of Non-official Drugs. The only disclosure of ingredients required by the old Act was that described above. The ingredients of products in the Pharmacopoeias or the Formulary can be determined by reference thereto, but only a small proportion of proprietary drugs disclose their formulae on their labels. Information as to the ingredients of such products was thought sufficiently important in the interests of public health to call for the inclusion in S. I944 of a provision requiring formula disclosure on the labels of non-official products. ${ }^{204}$ Objection to this provision was vigorous. It was contended to be of no value to the consuming public and destructive of the property rights of the manufacturers. So formidable did this opposition appear that in S. 2000 the requirement was modified by removing the necessity of stating the quantity or proportion of the active ingredients, their listing on the label in alphabetical order alone being required.205 In S. 2800, the provision was omitted entirely, but S. 5 as introduced in 1935 called for full formula disclosure. ${ }^{208}$ When passed by the Senate that year, however, it required only a listing of the active ingredients. But in S. 5 as it passed the Senate in 1937, this provision was importantly supplemented by a requirement, included in the enacted law, that the quantity or proportion of ig namet drugs and their derivatives be disclosed. ${ }^{207}$ These drugs, though not habit-forming, involve special dangers to the user, and, even though he may not know their hazards, yet, if harm should result from their use, notice of their presence will enable the physician to take proper steps to counteract their effect.

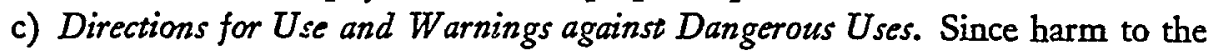
consumer may result from the absence of adequate directions for the use of drugs and since these were sometimes omitted in an effort to evade the old Act, ${ }^{208}$ it was thought wise to include in S. I944 the requirement that the label bear "complete and explicit directions for use."209 This was supplemented by a provision ${ }^{210}$ authorizing the Secretary to require by regulation further information on the label where necessary for the protection of health. In S. 2000 the situations in which this power could be exercised were made specific. The Secretary was authorized to require label warnings against use "in pathological conditions or by children where such use is con-

written prescriptions signed by licensed physicians, dentists, or veterinarians (not engaged in the business of dispensing drugs pursuant to diagnosis by mail) if the label bears the name and place of business of the dispenser, the serial number and date of the prescription, and the name of the prescriber. In the case of habit-forming drugs, the prescription must be marked non-refillable.

${ }^{20}$ Especially $\$ \$ 502(f)$ and $(j), 505,2$ IU. S. C. $\$ \$ 352(f)$ and $(j), 355$.

$20 \% 8(e)$. Such disclosure is required by law in a number of foreign countries. See KAIIET \& Schink, I00,000,000 Guinen Pigs (1933) 256.

$\$ 8(c)$.

${ }^{208} \$_{402}(\mathrm{e})$.

${ }^{307} \$ 502(\mathrm{~g}), 2$ I U. S. C. $\$ 352(\mathrm{~g})$. The drugs listed are alcohol, bromides, ether, chloroform, acetanilid, acetphenetidin, amidopyrine, antipyrine, atropine, hyoscine, hyoscyanine, arsenic, digitalis, digitalis glucosides, mercury, ouabain, strophanthin, strychninc, and thyroid. The Secretary is empowered to issue exempting regulations where compliance would be impracticable.

The exemption discussed in note 202, supra, is also applicable to drugs subject to this section.

${ }^{\infty 00} \mathrm{~A}$ direction for use in a given condition may imply a representation of efficacy in the treatment of that condition. Hence, directions were sometimes omitted in the labeling and conveyed by advertising. 200 \$8(d). $\approx 0 \% 8(\mathrm{c})$. 
traindicated and may be dangerous to health, and against unsafe dosage and methods of administration or application." ${ }^{11}$ The principal differences between these provisions and the enacted law lie in the substitution of "adequate" for "complete and explicit" directions and in making the requirement of warnings mandatory in the law rather than dependent upon regulations. ${ }^{212}$ The form adopted is more inclusive, - but it is also more vulnerable to constitutional attack. If this provision is upheld and sympathetically interpreted by the courts, it should operate to diminish materially the existing hazards of self-medication.

\section{Germicides}

A large and lucrative industry has developed purveying drugs to meet the demands of the germ-fearing American public. These products are usually simply labeled; some purport to be "germicides," others "antiseptics." Most consumers regard these terms as synonymous, but an antiseptic need not kill germs but merely inhibit their growth. The tests developed for determining the efficacy of germicides and antiseptics are of dubious adequacy, and, nnoreover, products which meet these tests under laboratory conditions may have little germicidal value under conditions of actual use, even when directions are followed. To cope with this situation, a rigorous provision ${ }^{213}$ was embodied in S. 1944 which called for a starement of the use for which a germicide or antiseptic was designed and the method and duration of application necessary to kill all micro-organisms with which the drug came in contact when so used. Permission was given to label such products as effective for specific kinds of micro-organisms only, in which event the drug would have to kill only such kinds.

Since so many of the products which would have been subject to this provision are of limited efficacy, compliance would have been possible for relatively few products unless label claims were sharply restricted. This prospect was far from attractive to the industry. Opposition was so vigorous as to force a retreat in S. 2800 to a requirement ${ }^{214}$ that the germicidal effect of the product, when tested under conditions "simulating as nearly as practicable the conditions" of use prescribed in the labeling, be equal to the germicidal effect of a specified dilution of phenol under a standard testing method. Moreover, S. 2800 also permitted the labeling as "antiseptics" of drugs which had merely inhibitory effect where these were designed for uses permitting prolonged contact with the body. ${ }^{215}$ Tests under conditions simulating those of actual use were attacked as impracticable, and S. 5, as passed by the Senate in 1935, merely provided ${ }^{216}$ that the term "antiseptic" should be deemed to have the same meaning as "germicide," with the exception as to inhibitory products noted above. This position, which represented a significant gain in consumer protection but left the approval of testing methods for judicial decision in individual cases, was carried into the enacted law. ${ }^{217}$ Here again the full disclosure requirement of
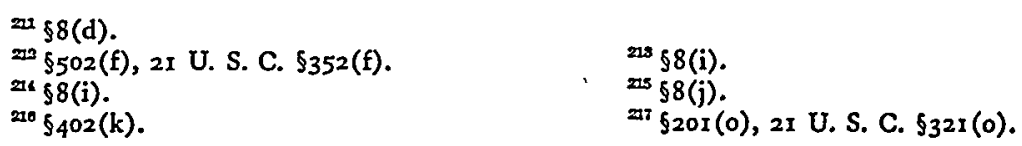
Section $201(\mathrm{n})$ may prove important. If a germicide is not germicidal in actual use, surely failure to indicate that fact would render the label misleading.

\section{Harmful Drugs}

The old Act contained no prohibition against harmful drugs. However lethal a drug might be, if it complied with its own standard of potency and was not misbranded, the F \& DA could not prevent its distribution. The definition of foods containing poisonous or deleterious ingredients as adulterated could not be duplicated in the case of drugs since many drugs must contain ingredients which are poisonous or deleterious if taken in excessive amounts or under unsuitable conditions. Accordingly, in S. I944 a drug was defined as adulterated "if it is or may be dangerous to health under the conditions of use prescribed in the labeling thereof."218 In S. 2000, "or may be" was deleted. ${ }^{219}$ In S. 5 an addition was made which served to excite Congressional attack; "or advertising" was inserted following "labeling."220 This made possible the seizure of a product by reason of statements made in its advertising. Senator Bailey inveighed against it in proposing the removal of the provision from the section on adulteration to that on misbranding where it would be subject to the drastic restriction on multiple seizure which he was advocating. ${ }^{221}$ As has been seen, Senator Bailey's move was successful, and the provision appears in the section on misbranding in the enacted law. ${ }^{222}$ Of course, with the subsequent excision of the advertising provisions from the bill, the phrase "or advertising" was deleted. ${ }^{223}$ In its final form, however, the provision constitutes an important contribution to consumer protection.

\section{Container Provisions}

No provisions with respect to drug containers were present in the old Act. S. 1944 required label declaration of the name and place of business of the manufacturer, packer, seller, or distributor and an accurate statement of the quantity of the contents. ${ }^{224}$ Drugs recognized in an official compendium were required to be packaged in accordance with the requirements, if any, of the compendium, ${ }^{225}$ and the Secretary was empowered to designate those drugs which are liable to deterioration and to require appropriate packaging thereof or a statement of precautions to be taken in view of the risk of deterioration. ${ }^{226}$ Containers misleading as to size, form, or fill were also declared misbranded.227 The prohibition in the old Act against drugs which are imitations of, or offered for sale under the names of other drugs was preserved. ${ }^{228}$

$$
2185_{4}(\mathrm{a}) \text {. } \quad 210 \S_{4}(\mathrm{a}), \quad 220 \$_{40 \mathrm{r}}(\mathrm{a})(\mathrm{r}) .
$$

2 See 79 Cong. Rec. 49r6-49r9 (I935). Senator Bailey, however, was content to leave "or advertising" in the section once it was transferred. And see note 242 , infra. The exercise of the power to seize a product because of representations made in its advertising would have posed the difficult problem of determining whether 2 given article's use had been affected by a given advertising statement.

$\$ 502(j), 2$ U. S. C. $\$ 352(j)$.

202 However, if a product is advertised as useful in a given condition, then that condition of use may become "customary or usual" and hence the full disclosure provision of $\$ 201(n), 21$ id. \$32r(n), would require warning of its dangerous character.
204 $56(\mathrm{~b})$.
$=28(\mathrm{~g})$.
$=\$ 8(\mathrm{~h})(\mathrm{I})$.
$=58(\mathrm{~h})(2)$. 
All the foregoing provisions were carried into the enacted law with minor modifications. 229

\section{New Drugs}

Reference has already been made to the provisions added to the bill in 1938 to prevent, if possible, a recurrence of the "Elixir Sulfanilamide" disaster. The regulatory device is of interest, not only for its intrinsic importance, but as illustrative of the difficulties of preventive controls in the drug field. The section stipulates in such detail as to preclude summarization in the text the types of information to accompany an application ${ }^{230}$ to the Secretary with respect to a new drug and the findings which, after hearing, must be made by him as a basis of an order refusing to allow the application to become effective. ${ }^{231}$ If no such order is made, the application becomes effective in 60 days. ${ }^{232}$ An effective application may be suspended if new evidence shows the drug to be unsafe or if the application is found to contain untrue material statements. ${ }^{233}$ Special provision is made for an appeal to the district courts from orders refusing or suspending applications. ${ }^{284}$ The Secretary is authorized to exempt by regulation new drugs used for experimental purposes by qualified experts. ${ }^{235}$

\section{Cosmetics}

I. Definition. The problem of coining a satisfactory definition of "cosmetics" proved a difficult one for the draftsmen of S. x944, and the definition contained in that bill ${ }^{236}$ was subjected to repeated formal changes. One significant exception was made in the enacted law; soap is specifically excluded. ${ }^{237}$ This exception first appeared in S. 5 as it passed the Senate in r935. The argument of the soap makers was that a definition of cosmetics which included soap would be followed by states in defining cosmetics in their cosmetic tax laws, a step to be deplored because "a tax on cleanliness is a tax on health."238 Whatever the merits of the case, with the excision of the advertising provisions from the bill, the objections to the exception lost most of their force for misleading claims for soap do not often appear in its labeling.

$\$ 502(\mathrm{~b}),(\mathrm{g}),(\mathrm{h}),(\mathrm{i}), 2$ I U. S. C. $\$ 352(\mathrm{~b}),(\mathrm{g}),(\mathrm{h}),(\mathrm{i})$.

200 The applicant must submit in full (I) reports of investigations as to the drug's safety, (2) a list of its components, (3) a statement of its composition, and (4) a description of methods, facilities, and controls used in its production, and (5) must provide samples of the drug and its components as required, and (6) specimens of proposed labeling. $\$ 505(\mathrm{~b}), 2 \mathrm{x}$ id. $\$ 355(\mathrm{~b})$.

201 Refusal orders may be based on any one of the following findings: ( $x$ ) the tests for the safety of the drug are not adequate; (2) the tests either show the drug to be unsafe or do not show it to bo safe; (3) the processes of manufacture are inadequate to preserve the drug's standards; (4) insufficient information is available to permit a finding that the drug is safe. $\$ 505$ (d), 21 id. \$355(d).

$\approx 2 \$ 505$ (c), 21 id. $\$ 355$ (c). But, where more time is needed for study, the Secretary, by notice, may postpone action on an application for 180 days from its filing.

${ }_{238} \$ 505(\mathrm{e}), 2 \mathrm{I}$ id. $\$ 355(\mathrm{e})$. The Secretary may also revoke a refusal order. Id. (f).

ser $\$ 505(\mathrm{~h}), 2 \mathrm{I} i d$. $\$ 355(\mathrm{~h})$. The findings of fact by the Secretary are conclusive if supported by sub. stantial evidence, leave being granted the applicant to adduce additional evidence where due explanation is given for the delay.

$\$ 505(i), 21$ id. $\$ 355(i)$. $\quad 200 \$ 2(c)$.

207 'The definition finally adopted reads as follows: "The term 'cosmetic' means ( $\mathrm{r}$ ) articles intended to be rubbed, poured, sprinkled, or sprayed on, introduced into, or otherwise applied to the human body or any part thereof for cleansing, beautifying, promoting attractiveness, or altering the appearance," together with their components, "except that such terms shall not include soap." \$20I(i), 2I U. S. C. $\$ 321$ (i).

${ }^{208}$ Statement filed by Seth Richardson, Atty. for Ass'n of American Soap and Glycerine Producers, Inc., Senate Hearings on $S .5$, at 2 r. 
It should be pointed out that a product normally regarded as a cosmetic, e.g. soap, may become a drug within the meaning of the Act if therapeutic effects are claimed for it.

\section{Adulterated Cosmetics}

a) Harmful Cosmetics. S. I944 declared a cosmetic adulterated if it "is or may be injurious to the user under the conditions of use prescribed in the labeling" or-to protect against inadequate precautionary labeling-"under such conditions of use as are customary or usual."239 Coupled with this was a grant of power to the Secretary to establish tolerances for, or to prohibit, poisonous or deleterious ingredients. ${ }^{240}$ These provisions led to an outcry by cosmetic manufacturers that, because of personal idiosyncrasies, almost all cosmetics were injurious to some users. A modification was made in S. 2000 to define as adulterated any cosmetic containing "any poisonous or deleterious substance which may render it injurious to the user" under the conditions described above. ${ }^{241}$ In this form the provision carried into the enacted law. ${ }^{242}$ However, the Secretary's power to prohibit harmful ingredients by regulation was deleted, chiefly at the insistence of hair-dye producers (whose products contain ingredients often causing harmful reactions). A proviso to the definition of adulteration ${ }^{243}$ excepted coal-tar hair dyes where the label bears a precautionary legend (the terms of which are prescribed) warning the user of the risk of skin irritation and directing the user's attention to accompanying directions for preliminary skin tests. The prescribed statement also includes a warning against the use of the dye on eyebrows or eyelashes, adding "to do so may cause blindness." The rigorous character of the statement seems to render it an adequate solution of a difficult problem.

b) Insanitary Ingredients. Provisions analogous to those in the food and drug sections directed against insanitary ingredients or conditions of manufacture and against contaminating containers were added to S. 5 in 1935 and enacted with no change. ${ }^{244}$ The use of certified coal-tar colors, except for hair dyes, was also required. 245

\section{Misbranded Cosmetics}

The broad definition of misbranding followed in the case of cosmetics the fortunes of the similar definition as applied to food and drugs. It appears in the new Act as "false or misleading in any particular."246

The new Act requires the label declaration of the name and place of business of the manufacturer, packer or distributor, and also of the quantity of the contents. ${ }^{247}$ A cosmetic is also misbranded if its container is so made, formed, or filied as to be misleading, ${ }^{248}$ a provision which the producers viewed with some alarm arising from the fanciful shapes of many cosmetic containers. The provision should afford protection against the disingenuous fancy of the chiseler.
$20055(a)$.
$200 \$ 5(b)$.
$212 \$ 5(a)$.

${ }^{9} \$ 60 \mathrm{~S}(\mathrm{a}), 2 \mathrm{I}$ U. S. C. $\$_{3} \in_{\mathrm{I}}(\mathrm{a})$. It is interesting to note that Senator Bailey's denunciation of inclusion in the drug adulteration section of drugs dangerous by reason of conditions of use prescribed in their labeling was not extended to the similar situation presented by this cosmetic section.
${ }_{203}^{2}$ Ibid.
$24 \$ 60 \mathrm{I}(\mathrm{b}),(\mathrm{c}),(\mathrm{d}), 2 \mathrm{I} i d . \$_{36 \mathrm{I}}$ (b), (c), (d).
${ }^{25} \varsigma_{60 \mathrm{I}}(\mathrm{c}), 2 \mathrm{I}$ id. $\$_{36 \mathrm{I}}(\mathrm{c})$. The Secretary is authorized to list harmless colors and certify batches thereof. $\$ 604,21$ id. $\$ 364$.
${ }^{317} \$ 602(b), 21$ id. $\$ 362$ (b).
${ }^{218} \$ 602(a), 2 x i d . \$ 362$ (a).
${ }_{2 \times s} \$ 602(d), 21$ id. $\$ 362$ (d). 
III

The reader who has persevered through the intricacies of the foregoing analysis will appreciate the difficulty of appraising the law as a whole. However, if he has checked the differences between S. I944 and S. 2000, I think he will agree with me that the cry of "emasculated" which arose when the latter was introduced was without justification. ${ }^{249}$ Only the politically naive could have anticipated the enactment of the first bill without change. No bill where opposition is significant escapes unscathed. It is arguable that S. I944 was too drastic, that if a less rigorous bill had been introduced it would have ultimately emerged as a stronger act than the one which descended from S. I944. On the other hand, if the draftsmen had begun with a bill in the very terms of the enacted law, it is certain that it would have been materially modified by amendment. When the initial shock occasioned by S. 1944 wore off, the affected industries established tolerances for provisions which at first they viewed with abhorrence.

The rejection of the advertising provisions represent the principal defeat for the proponents of the bill. Even there the defeat was not total for the powers of the FTC over advertising in this field were materially strengthened. While I think the results which the $\mathrm{F} \& \mathrm{DA}$ could have achieved if it had been vested with advertising control may easily be exaggerated, that very fact renders me all the more pessimistic as to the possibilities of FTC regulation, sanctioned as it is by penalties of little deterrent value and vested in a body whose record is far more distinguished in other branches of its jurisdiction than in the control of food, drug, and cosmetic advertising. ${ }^{200}$

The new procedural provisions cannot be assayed with accuracy until administrative experience has accumulated. I believe, however, that the granting of the new remedy of injunction and other procedural improvements should outweigh such regressive effects as the limitations on the seizure power and the restrictions on venue may have. The provisions for judicial review of regulations, while affording some cause for anxiety, can finally be appraised only after the courts have spoken.

Putting the advertising issue to one side and resolving favorably such doubts as the procedural and regulatory provisions inspire, I am convinced that the new law represents a vast improvement over the old one, a gain well worth the five years of unremitting effort on the part of its Congressional champions, of the F \& DA, and of the women's organizations which were its most active public supporters.

A perfect law has not been achieved. That must wait upon the education of the consumer, the spreading of a sense of public responsibility within the affected industries, and the extension of medical care on terms within reach of those who now rely upon the radio and advertising pages for diagnosis and prescription. Progress along all three lines is evident.

\footnotetext{
${ }^{20}$ It should be conceded that some procedural changes, not discussed in this article, were introduced at that time which would have to be weighed in appraising the two measures, notably the elimination of the minimum fine for violation. I do not believe, however, that they represented major concessions.

${ }_{250}$ Since the enactment of the Wheeler-Lea Act, I understand that the internal organization of the FTC handling food, drug, and cosmetic matters has been importantly altered, no doubt with a view to greater efficiency in consumer protection.
} 